\title{
GEVLEUGELDE BEELDEN
}

\section{Observaties aAN VOGEls in de NederLANDSE SCHILDER- KUNST VAN DE ZEVENTIENDE EN ACHTTIENDE EEUW*}

Eén van de aantrekkelijkste schilderijen van de befaamde Dordtse kunstenaar Aelbert Cuyp is het portret van de eend Sijctghen (afb. I). Het is een uitzonderlijk werk in de Nederlandse kunstgeschiedenis, want eenden werden zelden


blijkt dat zij in I647 als twintigjarige boereneend was geschilderd en, volgens enkele later toegevoegde regels, drie jaar later was overleden. Per jaar had zij honderd eieren gelegd, waarvan er drie zijn afgebeeld. Of Cuyp zelf het initiatief nam tot het schilderen of in opdracht werkte, is helaas onbekend. Hoe dan ook, het schilderij was, behalve een bijzonder kunstwerk, een dierbare herinnering voor de eigenaar van de eend, een trotse boodschap over een fenomeen voor het nageslacht én een locaal nieuwscommuniqué aan de eigentijdse buitenwereld.

Tegenwoordig verschijnen vogels regelmatig op de televisie. Dit maakt een kunsthistoricus die ook vogelaar is - en dus in de natuur naar vogels kijkt benieuwd naar de aanwezigheid van gevogelte in visuele media uit vroeger tijden, dat wil zeggen in schilder- en beeldhouwkunst, tekeningen en grafiek (inclusief boekillustraties). In de zeventiende en achttiende eeuw, de periode waarom het hier gaat, waren kunstwerken vaak drager van een algemene boodschap, zelfs al was hun bereik klein. Kunstenaars konden politieke, religieuze, morele, sociaal-economische en artistieke omstandigheden steunen of er kritisch commentaar op leveren. Vogels waren een belangrijk motief in de geschilderde communicatie van toen. Soms spelen zij de hoofdrol, in andere gevallen maken zij zijdelings deel uit van de voorstelling. In deze bijdrage wordt nagegaan hoe het is gesteld met de aanwezigheid, functie en betekenis van vogels in de Nederlandse schilderkunst van de Gouden Eeuw en de tijd van de Verlichting. Gelet op de aantrekkelijkheid van het onderwerp en de algemene belangstelling voor vogels is het merkwaardig dat aan dit onderwerp nooit een omvangrijke publicatie is gewijd. Terwijl over bijvoorbeeld bloemstillevens in de oude Noord- en Zuid-Nederlandse kunst fraaie catalogus na indrukwekkende monografie verschijnt, blijft het perspectief voor vogels beperkt tot waardevolle maar

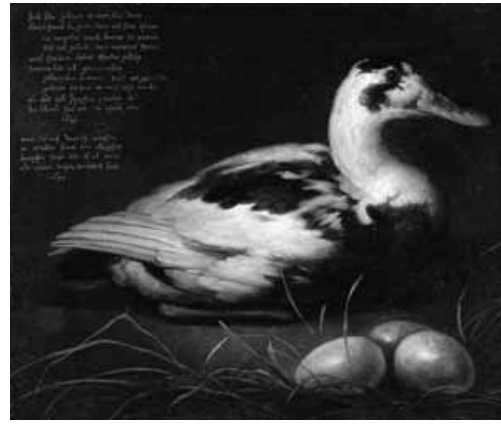

1 Aelbert Cuyp, 'Portret van Sijctghen', 1647-1650. (Zie kleurenkatern II, 1) 
niet 'definitieve' boeken over Melchior d'Hondecoeter en Aert Schouman, passages in overzichtswerken van Nederlandse kunst, entries in collectiecatalogi, artikelen over deelonderwerpen als vogels in genrestukken, of verwijzingen in tentoonstellingscatalogi. ${ }^{2}$

Het doel van deze bijdrage is tweeledig. In grote lijnen wordt geschetst op welke manier vogels in een aantal schilderkunstige genres zijn vertegenwoordigd. Daarnaast wordt deze verkenning begeleid door observaties en vragen vanuit de veldornithologie. Deskundigen op het gebied van herkenning, gedrag, leefwijze en biotopen van vogels hebben zelden hun licht laten schijnen over de schilderkunst. Het aantal onjuiste determinaties van vogels in de kunsthistorische literatuur - waardoor interpretaties van schilderijen er volkomen naast kunnen zitten - is overstelpend. ${ }^{3}$ Bovendien worden intussen achterhaalde vogelnamen zoals die indertijd op tekeningen zijn gezet vaak gemakzuchtig overgenomen. Maar ook vragen naar de juistheid van het getoonde gedrag en naar de geschilderde entourage zijn nooit met nadruk gesteld.

Wat volgt is niet meer dan een oriëntatie die aantoont dat een tweevoudige invalshoek nieuwe kennis over kunst in de zeventiende en achttiende eeuw zal kunnen opleveren. In aanmerking komen alleen kunstwerken waarin vogels visueel of inhoudelijk prominent aanwezig zijn. Het accent ligt op wilde dieren, al komen ook medebewoners van Sijctghens erf voor het voetlicht. Omdat vogels in de schilderkunst, bij alle verscheidenheid aan thema's en onderwerpen, niet over één kam kunnen worden geschoren, heb ik de tekst opgebouwd op basis van een indeling in genres met de twee vogelschilders pur sang Hondecoeter en Schouman als climax. ${ }^{4}$ Ik begin met het stilleven. Het 'levend gevogelte', zoals het in contemporain jargon heette, komt daarna aan de orde.

\section{'Dood gevogelte': het jachtbuitstilleven}

Het jachtstilleven of, om een passender begrip te hanteren, jachtbuitstilleven, kwam in de Nederlanden tot bloei in de tweede helft van de zeventiende eeuw. ${ }^{5}$ De geschilderde weergave van dood wild en gevogelte in een binnenruimte of in de buitenlucht kwam voort uit keuken- en marktstukken uit de late zestiende en vroege zeventiende eeuw van Pieter Aertsen en Joachim Beuckelaer. ${ }^{6}$ Details hieruit werden geïsoleerd en tot zelfstandige varianten van het stilleven ontwikkeld. Deze specialisatie viel samen met een internationale ontwikkeling die aan het begin van de zestiende eeuw was ontstaan: die van het stilleven met een hangende dode vogel - wild en gevogelte werden opgehangen om het vlees goed te houden. Een beroemd vroeg voorbeeld is het schilderij met een Patrijs (1504; Alte Pinakothek, München) van de in I500 naar Duitsland verhuisde Italiaan Jacopo de Barbari.7

Nederlandse kunstenaars moeten op de hoogte zijn geweest van dergelijke taferelen met ‘dood gevogelte'. In de Zuidelijke Nederlanden leverde de ontwik- 


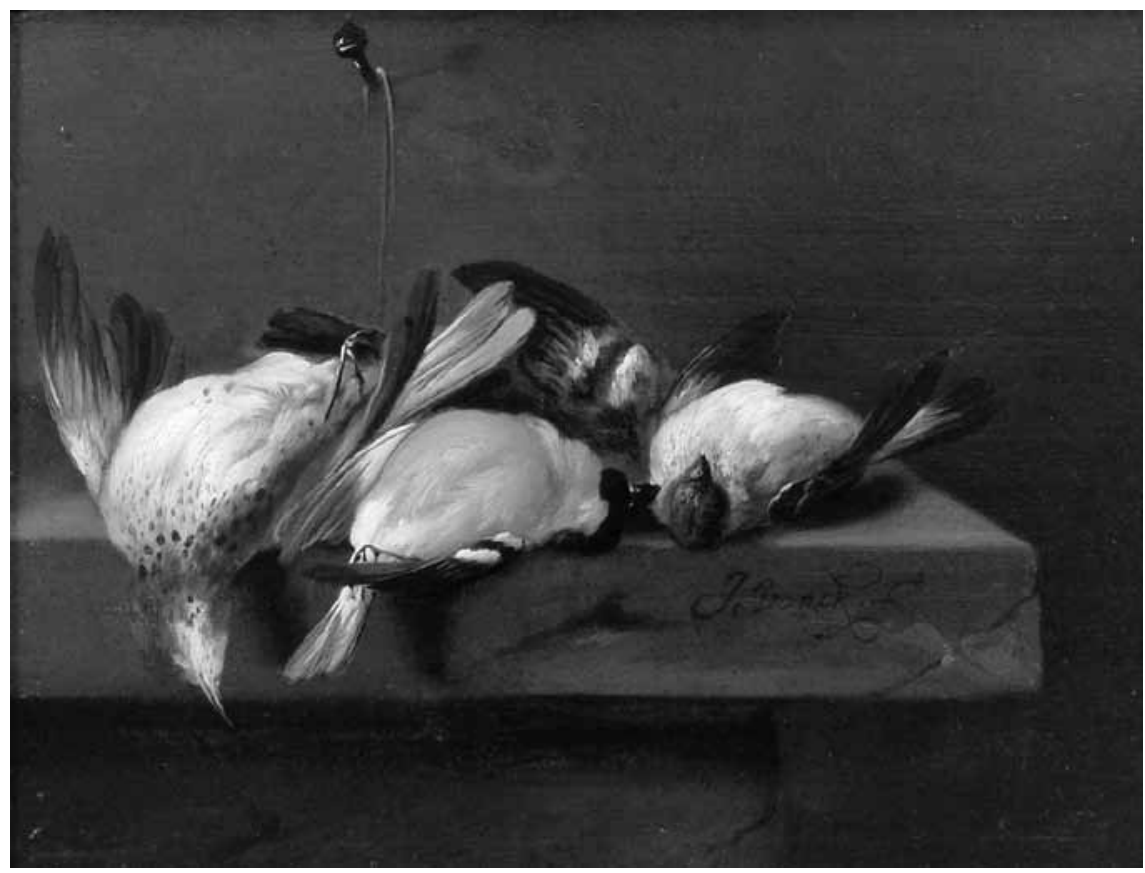

2 Jan Vonck,

'Stilleven met dode vogels', paneel, $25 \times 34,3 \mathrm{~cm}$. Bron: Dordrechts Museum, Dordrecht

keling van het jachtbuitstilleven andere resultaten op dan in de Republiek. Zuidelijke kunstenaars als Frans Snijders en zijn leerling Joannes Fijt schilderden rijke pronkstillevens waarin naast dood gevogelte en wild - waarvan ieder veertje of haartje precies was geschilderd - ook groente en fruit, porselein en zilver werden geplaatst. Deze stukken waren ongetwijfeld bestemd voor een publiek van adel en welgestelde burgers. Geschilderde provisiekamers bewezen hoe rijk én gastvrij de eigenaar was. Veel van dergelijke stillevens geven geen beeld van de werkelijkheid; de voorwerpen werden voor dat ene schilderij gearrangeerd. ${ }^{8}$

In de Noordelijke Nederlanden had het jachtbuitstilleven zich pas na I635I640 ontwikkeld. Deze stillevens waren aanvankelijk eenvoudiger. De eerste Noordelijke vertegenwoordigers van het genre, zoals Elias Vonck en later zijn zoon Jan, schilderden meestal op een vinkenbaan gevangen zangvogels, soms aangevuld met een kooi met lokvink of een slagnet (afb. 2).

Het zogenoemde vinken was een in Nederland veel beoefend tijdverdrijf en nevenberoep. ${ }^{9}$ Naast dergelijke specialisten waren er kunstenaars die incidenteel voor dit genre kozen. Uitgerekend het enige stilleven van Rembrandts hand (circa I639; Rijksmuseum, Amsterdam) laat twee dode pauwen zien. Een meisje kijkt toe, leunend op een vensterbank. Aan de interpretatie van dit raadselachtige meesterwerk zijn veel woorden vuilgemaakt, maar tot een definitieve conclusie is tot nu toe niemand gekomen. ${ }^{\text {I० }}$

Rembrandts tijdgenoot Cornelis Lelienbergh en iets later Jacob en Cornelis Biltius waren wél specialisten. Jacob Biltius' trompe l'oeil-schilderijen van aan een muur gehangen vogels (afb. 3), soms aangevuld met jachtattributen, 
3 Jacob Biltius, 'Dode snip', ${ }_{1663}$, olieverf op doek, $65 \times 58 \mathrm{~cm}$.

Bron: Fries Museum, Leeuwarden, inv.

So7869 (legaat S.A.в. Taconis, 1928)

\section{Johannes}

Leemans, 'Stilleven met geweer en andere jachtattributen', 1665, doek, 82,3x 165,9 cm. Bron: Dordrechts Museum, Dordrecht (bruikleen Instituut Collectie Nederland, Rijswijk/ Amsterdam)
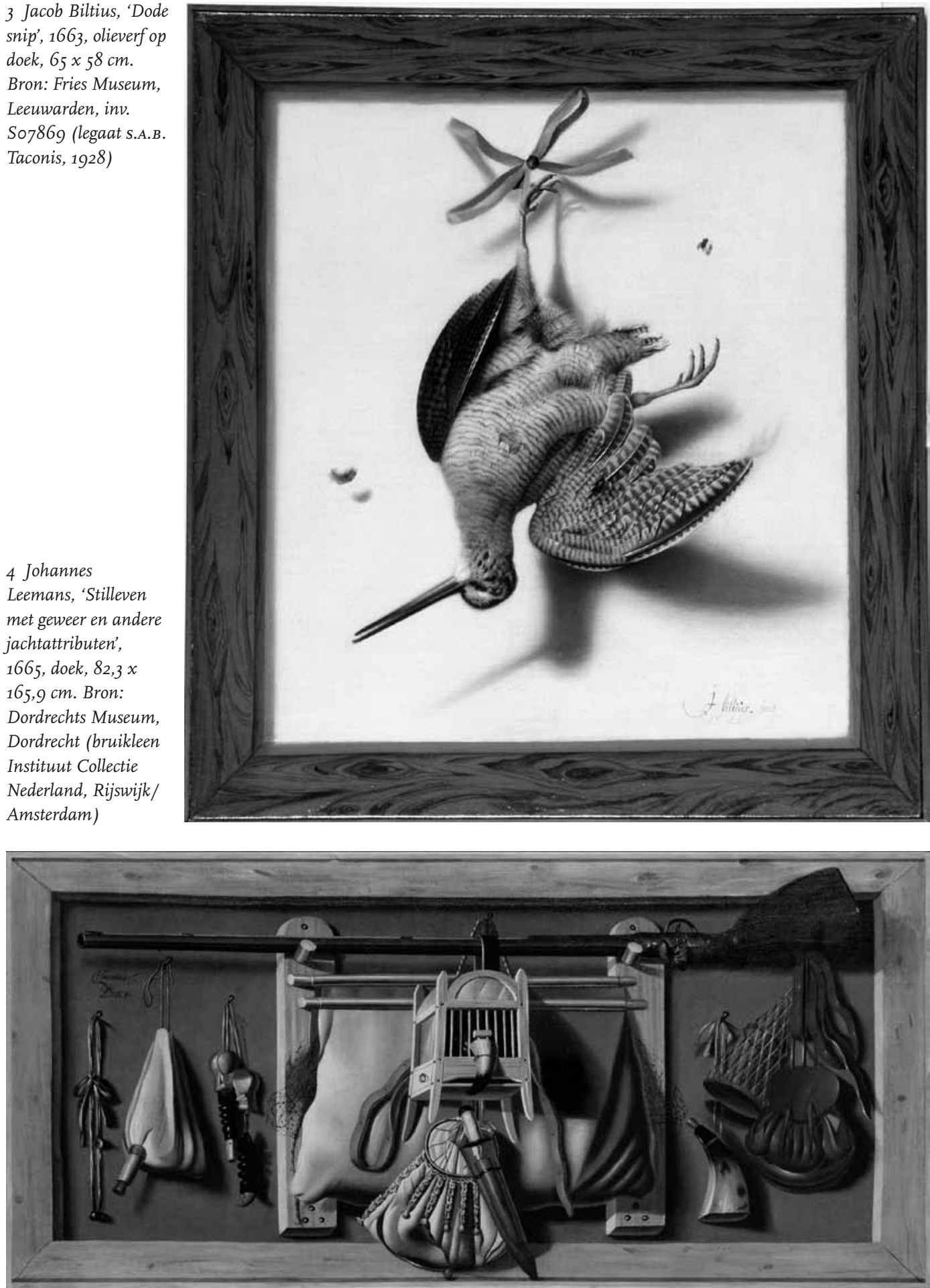
moeten in zijn woonplaats Den Haag in de smaak zijn gevallen bij het hof van Oranje en de internationale adel. ${ }^{\text {II }}$ Andere kunstenaars kozen voor een repertoire van 'bedriegertjes' (trompe l'oeil-voorstellingen) met jachtattributen zónder vogels. Onder hen verwierven Anthonie en Johannes Leemans een uitstekende reputatie (afb. 4). Zulke bedrieglijk precies geschilderde voorstellingen waren zeer in trek.

Stillevens met dode vogels uit de zeventiende eeuw worden doorgaans geassocieerd met de jacht. Tot in deze tijd was die voorbehouden aan hof en adel. Er was wettelijk vastgelegd wanneer door wie welke dieren mochten worden bejaagd en in welke hoeveelheden. In de loop van de zeventiende eeuw werd steeds soepeler omgegaan met deze bepalingen ten gunste van de gegoede burgerij, die zich graag de adellijke levensstijl aanmat. Aan het einde van de eeuw werd de jacht dan ook een vrijetijdsbesteding voor de gegoeden, zeker die met een eigen landgoed. Daarnaast legden bezitters van buitenplaatsen vinkenbanen aan, waar bewoners en bezoekers zich gezamenlijk vermaakten. ${ }^{\text {I2 }}$

De vele jachtbuitstillevens wijzen op een zekere populariteit van het genre, ook al werd het stilleven in theorie weinig gewaardeerd. ${ }^{\mathrm{I} 3}$ Er moeten ook nietadellijke kopers zijn geweest die graag werden geassocieerd met de jacht en, behalve stillevens, jachtportretten en jachttaferelen bestelden. Precieze gegevens over kopers van jachtbuitstillevens en hun motieven zijn nauwelijks bekend. ${ }^{\mathrm{I}}$ Wel is duidelijk dat er aanzienlijke prijsverschillen waren. Joannes Fijt kon ruim verdienen: hij ontving voor een dag werken vijftien maal zoveel als een Antwerpse meestertimmerman. Fijn en gedetailleerd geschilderde gecompliceerde stillevens zoals de zijne waren in de zeventiende eeuw het meest in trek. Cornelis Lelienbergh en andere schilders met een breder penseel ontvingen heel wat minder. ${ }^{15}$

Het jachtbuitstilleven kwam in de Noordelijke Nederlanden tot grote bloei in de laatste decennia van de zeventiende en de eerste van de achttiende eeuw dankzij onder meer Willem van Aelst, Melchior d'Hondecoeter, Jan Baptist Weenix en diens zoon Jan. Zij verfijnden het stilleven met op een tafel of balustrade neergelegde of aan een kale muur opgehangen vogels tot subtiel geschilderde, sierlijke, soms overvloedige en monumentale composities, met een tuin, buitenplaats of berglandschap op de achtergrond. De vogels waren nu eerder trofeeën dan toekomstige ingrediënten van een maaltijd. De Noord- en ZuidNederlandse aanpak viel bij deze kunstenaars samen. Hun werk paste volmaakt in de smaak van hun tijd waarin verfijning, elegantie en het decoratieve de boventoon voerden.

Na deze generatie begaafde kunstenaars verdween het genre niet uit beeld. Toen gedurende de laatste decennia van de achttiende eeuw Nederlandse kunstenaars en hun publiek aansluiting zochten bij de Hollandse traditie van de Gouden Eeuw om het veronderstelde verval in de beeldende kunst te keren, grepen sommige schilders terug naar voorbeelden van jachtbuitstillevens uit die tijd. ${ }^{16}$ Een eenvoudige versie - mét Patrijs - schilderde Willem van Leen in 


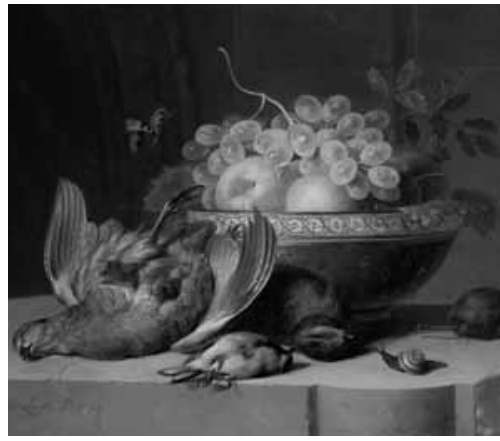

5 Willem van Leen, 'Stilleven', 1798.

(Zie kleurenkatern II, 2)

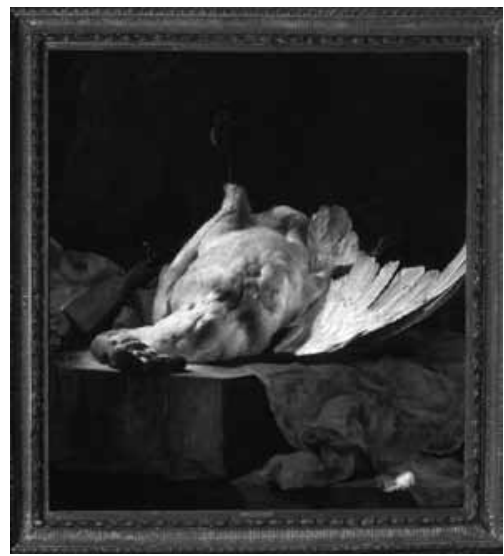

6 Jan Baptist Weenix, 'Stilleven met dode zwaan', circa 1651. (Zie kleurenkatern II, 3)
I798 (afb. 5). Dat het genre ook later nog status had, blijkt uit de prijsvraag die het tekendepartement van het genootschap Felix Meritis in I8I3 uitschreef voor een schilderij 'met onderscheiden Dood Wild'. In de tentoonstellingen van levende meesters, geïnitieerd door Lodewijk Napoleon, waren nog altijd schilderijen met vogels te zien. ${ }^{17}$

Het soortenspectrum van de afgebeelde vogels veranderde omstreeks 1700 in zoverre, dat de opbrengst van verschillende soorten jacht werd gemengd zodat een dode zwaan nu kon liggen naast Vinken en IJsvogels. Tot de vogels die frequent in jachtbuitstillevens voorkomen behoren Patrijs (die smakelijk én fraai werd gevonden), Roerdomp, Blauwe Reiger, Wilde Eend, Watersnip en pauw (meestal Blauwe Pauw). ${ }^{18}$ Zwanen en pauwen werden in de rijke dis fraai opgemaakt op tafel geplaatst, zoals diverse Vlaamse keukenstukken laten zien. Zij moeten een aantrekkelijk motief voor de schilder zijn geweest, zeker zwanen, omdat het schilderen van wit kunstenaars een bijzondere uitdaging bood (afb. 6). ${ }^{\text {19 }}$

Kunstenaars hebben hun vogels zelf gevangen, op de markt gekocht of direct betrokken bij 'vogelaars' (vogelvangers). Ook kregen zij vermoedelijk 'modellen' door de opdrachtgever aangeleverd. Dit houdt in dat veel vogels die in jachtbuitstillevens voorkomen in Nederland waren gevangen. Het zou interessant zijn de geschilderde vogels per soort te inventariseren en daar, met enige omzichtigheid, conclusies aan te verbinden over hun voorkomen.

Bovendien kan men op grond daarvan meer zeggen over de wijze waarop een kunstwerk tot stand kwam. Zoals men in een bloemstilleven door een secure inventarisatie kan ontdekken dat allerlei soorten nooit tegelijk kunnen bloeien en dus niet in kort tijdsbestek naar de natuur geschilderd kunnen zijn, is het mogelijk in stillevens specifieke zomer- en wintervogels aan te wijzen. Een combinatie van beide zou aangeven dat de kunstenaar één of meer jaargetijden heeft gewacht met het voltooien van het schilderij, óf zijn compositie naar tekeningen heeft samengesteld. ${ }^{20}$

Welke boodschap werd er via deze vogels uitgedragen? Hierop is geen pasklaar antwoord te geven. ${ }^{21}$ Hoewel bijvoorbeeld Patrijzen en pauwen in een bepaalde context stonden voor wellustigheid respectievelijk trots, bieden de stillevens waarin zij voorkomen vaak te weinig aanknopingspunten voor méér dan associaties. ${ }^{22}$ Mogelijk verwijzen sommige stukken naar de vergankelijkheid.

Een aantal van deze schilderijen diende als louter decoratie, als bewijs van macht en welvarendheid van opdrachtgever of bezitter, of als blijk van diens 
vaardigheden als schutter of als teken van diens gastvrijheid. ${ }^{23}$ In het laatste geval kunnen jachtbuitstillevens worden geassocieerd met het leven op en de gaven van het land, ook op landgoederen, waar een overvloedige oogst aan wild, gevogelte, groenten en fruit wachtte. ${ }^{24}$ Andere mogelijkheden zijn dat zij Gods gulle gaven aan de mens tonen. In enkele gevallen werd de schoonheid van de natuur bezongen. ${ }^{25}$ Voor niet-jagende burgers gaven jachtbuitstillevens toegang tot voorwerpen en gewoonten die financieel buiten hun bereik lagen.

In ieder geval bewijzen jachtbuitstillevens de vaardigheden van de schilder. Een los veertje of een bloeddruppel, liggend naast een dode zwaan of vallend van een hangende Watersnip, benadrukten het vermogen van de kunstenaar illusies te scheppen. Een kunstenaar kon vaak zelf het onderwerp en de moeilijkheidsgraad van zijn stilleven bepalen, zodat hij met andere kunstenaars kon wedijveren. Sommige schilders zochten vooral verdieping door hetzelfde motief te herhalen, andere kozen voor variatie. ${ }^{26}$

Bij al dit jachtgeweld zou men bijna vergeten dat in de zeventiende en achttiende eeuw in sommige landen bepaalde vogelsoorten al bescherming genoten. In hoeverre de beschermingsgedachte in die tijd door Nederlandse kunstenaars via andere genres werd uitgedragen zou moeten worden onderzocht. ${ }^{27}$

'Levend gevogelte': het historie- en genrestuk en het portret

Ik vervolg mijn rondgang langs de genres met het historiestuk, waarvan de onderwerpen werden ontleend aan geschiedenis, mythologie en religie en dat door veel gezaghebbende auteurs over kunst en kunstenaars in de zeventiende en achttiende eeuw als het belangrijkste genre werd beschouwd. Een goede historieschilder was universeel en bezat een bijna encyclopedische kennis, ook over de natuurlijke historie. De ideale historieschilder was een intellectueel die voor zijn composities het fraaiste uit de natuur selecteerde en niet - zoals de beschuldiging aan het adres van de stillevenschilder luidde - de natuur klakkeloos kopieerde. Ook in de Nederlanden is het historiestuk beoefend, zij het dat het met het ultieme ideaal van de historieschilder in de praktijk niet zo'n vaart liep. ${ }^{28}$ Of jachtscènes, anders dan jachtportretten, ertoe kunnen worden gerekend is onduidelijk. Allegorieën in ieder geval wél.

Voor historieschilders waren allerlei onderwerpen beschikbaar waarin vogels een belangrijke rol voor zich opeisten. Niet voor niets vinden wij in sommige zeventiende-eeuwse teken- en modelboeken een sectie met vogels. Zo is in 't Light der teken en schilderkonst van de tekenleraar Crispijn van de Passe dat met ingang van $\mathrm{I} 643$ in delen verscheen, een hoofdstuk met twaalf platen opgenomen over 'De rechte manier om alderhande Vogelen op een seer lichte wijse te teeckenen'. Van de Passe koos vijf typen proporties - die van arend, uil, 
zwaan, Ooievaar en haan - die de gebruiker van het tekenboek op weg hielpen om op basis van geometrische vormen alle soorten vogels te tekenen. Alles wat God heeft geschapen, dus ook de vogel, heeft volgens Van de Passe (en vele tijdgenoten) te maken met mathematiek. Omdat het tekenen en schilderen van een levende en beweeglijke wilde of tamme vogel lastig kon zijn, kwam hij met een suggestie: de kunstenaar nagelde simpelweg een dode vogel in de gewenste houding op een blok. Zo kon 'de naturelijcke Actie der Vogelen' in acht worden genomen. ${ }^{29}$

Gewapend met een all-round opleiding kon de historieschilder zijn kennis van vogels uitbaten in gevarieerde onderwerpen, van 'Orpheus betovert de dieren' tot 'Adam en Eva in het Paradijs' of 'De Ark van Noach'. ${ }^{\circ}$ Andere onderwerpen beperkten de keuze tot één vogel: 'Leda en de zwaan', of 'De roof van Ganymedes'. Mythologische en bijbelse onderwerpen die het mogelijk maakten veel vogels in één tafereel onder te brengen, vinden we vooral in de Nederlandse schilderkunst van de vroege zeventiende eeuw, bij Jan Brueghel de Oude en Roelant Savery. Zij ontwikkelden thema's met dieren, waaronder inheemse en exotische vogels, tot een specialisme. Savery's capaciteiten blijken uit zijn liefst 2I versies van het Orpheusverhaal. ${ }^{3 \mathrm{I}}$ Mogelijk verwijst de veelheid aan dieren bij deze kunstenaars naar de overvloed in Gods schepping.

De meeste vogels die in hun taferelen zijn afgebeeld zouden elkaar in het wild niet kunnen tegenkomen. Zij zijn verenigd in een ideale 'visuele biotoop' vanwege het verhaal én om de veelzijdige kennis van de kunstenaar kenbaar te maken die was opgedaan in menagerieën en naturaliënkabinetten. De belangstelling van Brueghel en Savery lijkt te zijn geïnspireerd door wetenschappelijke fascinatie voor de natuur en de artistieke vertaling hiervan bij een aantal vorstenhoven, zoals dat van keizer Rudolf II in Praag, waaraan een menagerie was verbonden. ${ }^{22}$ Savery kon hier studeren en daarmee zijn 'wetenschappelijke' attitude demonstreren, een historieschilder waardig. Hij moet zijn vogels scherp hebben bekeken: ze zijn meestal zeer herkenbaar.

Na de dood van Roelant Savery in I639 nam de belangstelling voor dierrijke voorstellingen in de Nederlandse historieschilderkunst af, maar verdwenen mythologische en bijbelse vogels niet uit beeld. In het al genoemde verhaal van de roof van Ganymedes, dat ook voorkomt in Ovidius' Metamorfosen, speelt een niet nader gespecificeerd soort arend de hoofdrol. Ganymedes werd tijdens het weiden van vee op last van Zeus door een arend (volgens sommige bronnen Zeus zelf) weggevoerd en naar de Olympus gebracht. Zeus was onder de indruk van de schoonheid van de jongeling. Uiteindelijk werd Ganymedes schenker van nektar en ambrozijn tijdens goddelijke feestmalen. Wellicht het bekendst is de variant die Rembrandt in I635 schilderde (Gemäldegalerie Alte Meister, Dresden). Ganymedes is hierin een huilend kind, dat tijdens de ontvoering plast: mogelijk een satirische verwijzing naar Aquarius. 33 De arend is niet te determineren. Bij een zich in Griekenland afspelend verhaal kan men zich allerlei soorten arenden voorstellen, maar het is de vraag of Rembrandt zich 
daarover druk maakte. Misschien hechtten zeventiende-eeuwse kunstenaars in dit verband meer aan de suggestie (een grote roofvogel met een enorme snavel), aan de waarschijnlijkheid, dan aan een volledig natuurgetrouwe afbeelding.

In allegorische voorstellingen keren vogels regelmatig terug. In reeksen van de vier elementen, die tot in de zeventiende eeuw populair waren, is de lucht vaak verbeeld in de gedaante van een vogel.34 Dat vogels nadat zij waren geschilderd alsnog van een allegorische betekenis konden worden voorzien, bewijst de geschiedenis van het bekende schilderij De Zwaan van Jan Asselyn, geschilderd in de jaren veertig van de zeventiende eeuw. Na het overlijden van Asselyn in I652 is, mogelijk op gezag van de toenmalige eigenaar, onder de dreigende zwaan 'Raad-pensionaris' geschreven, op een van de eieren in het nest 'Holland' en boven de zwemmende hond 'De Viand van de Staat'. Zo werd op emblematische wijze de waakzaamheid van Johan de Witt voorgesteld, de in 1653 benoemde raadpensionaris die de Nederlandse staat later, fier als een zwaan, zou verdedigen. 35

In veel genrestukken uit de zeventiende en achttiende eeuw zijn vogels aan te treffen. Vaak ziet hun aanwezigheid er, vanwege het ogenschijnlijk realistisch gehalte van het kunstwerk, vanzelfsprekend uit en zijn zij niet prominent in het beeld aanwezig; desondanks droegen zij vaak in belangrijke mate bij aan de betekenis van het schilderij. Het behoort langzamerhand tot de algemene kennis van het cultureel geïnformeerde publiek dat achter veel ogenschijnlijk alledaagse taferelen uit de zeventiende eeuw dubbelzinnigheden en moralistische vermaningen schuilgaan. Deze zijn vaak gebaseerd op dubbele betekenissen van begrippen in de taal. Om me tot de ornithologie te beperken: de begrippen vogel, vogelen (vogels vangen of bejagen) en vogelaar (vanger van vogels) stonden in de zeventiende eeuw voor respectievelijk het mannelijk geslachtsdeel, de liefde bedrijven en de mannelijke participant in deze activiteit. Een 'kip' was een prostituee, een 'haan' de onkuisheid of een liefhebber van vrouwen. ${ }^{36}$ Eveneens werd gespeeld met de dubbelzinnige betekenis van het begrip 'jagen', dat in de zeventiende eeuw ook stond voor het bedrijven van de liefde en de minnejacht. 37 Daarnaast werden vogels uit spreekwoorden gevisualiseerd. Uilen, die regelmatig in genrestukken terugkomen, waren, afhankelijk van de situatie, spreekwoordelijk wijs óf dom en dwaas (omdat zij aan de duisternis boven het licht de voorkeur geven)..$^{8}$

Zangvogels in kooitjes of manden behoren inmiddels, vooral dankzij de publicaties van Eddy de Jongh, weer tot de bekende beeldtaal uit die periode. Stond de vogelkooi sinds de vroeg-christelijke tijd voor het menselijk lichaam en de vogel voor de ziel, in de zeventiende-eeuwse genreschilderkunst hadden kooi en vogel een amoureuze betekenis. Man of vrouw kon, als een vogel, aangenaam in de liefde zijn opgesloten. Erotisch zijn de kooi als het vrouwelijk 
geslachtsdeel en de vogel als de maagdelijkheid, die verloren gaat bij het ontsnappen van de vogel. 39

Andere mogelijkheden bood het beeld van een vogel aan een touwtje. Zangvogels dienden in de zeventiende eeuw vaak als kinderspeelgoed. Zij werden met een draadje aan een poot vastgebonden. Het andere eind van de draad was soms bevestigd aan een kruk, een T-vormig stukje hout dat ook als zitplaats voor de vogel diende. De vogel diende als erotisch symbool of stond, minder positief, voor de 'gevangenschap' van de liefde. In de emblemataliteratuur is naast de erotische ook een religieuze betekenis te vinden: de liefde voor God. De Distelvink aan een draadje keerde steeds terug tot zijn kruisvormige houvast. $\mathrm{Al}$ ouder is de interpretatie van de Distelvink als de menselijke ziel: de jonge Jezus of Johannes de Doper speelt in voorstellingen met de Heilige Familie vaak met een Puttertje. ${ }^{\circ}$

Voor lang niet alle genrestukken staat vast dat de schilder of de eigentijdse toeschouwer er een symbolische betekenis aan toekende. Bovendien zullen kunstenaars ook schilderijen uitsluitend om esthetisch plezier hebben vervaardigd. Hoe dan ook, van een enorme soortenrijkdom in de genreschilderkunst is geen sprake. Het zal duidelijk zijn dat vogels in genrestukken vrijwel altijd in kunstmatige omstandigheden zijn afgebeeld. Zeker bij vogels in kooitjes was vaak minder belangrijk welke soort de vrijheid koos: het was voldoende dat het 'een vogel' was.

\section{Het portret}

Het portret is niet bepaald het genre dat de kunstliefhebber snel associeert met vogels. Toch zijn ook in portretten met enige regelmaat vogels aanwezig, vooral in die van jagers en valkeniers, al dan niet met hun familie. In deze categorie zijn allerlei varianten te onderscheiden: er zijn jagende volwassenen en kinderen met een valk op de arm, familieportretten in de buitenlucht waar de buit trots wordt gepresenteerd, of voorstellingen waarin de vader triomfantelijk van de jacht terugkeert, zonder uitzondering met vogels of een haas. Jachtportretten uit de zeventiende en achttiende eeuw hadden te maken met de status die nodig was om de jacht te kunnen beoefenen. De wens van ambitieuze burgers en vertegenwoordigers uit de regentenklasse zich met de jacht bezig te houden, of zich er tenminste mee te associëren, is te herkennen in de toename van het aantal geschilderde jachtportretten. Zo schilderde Jacob Gerritsz. Cuyp de zesjarige Michiel Pompe van Slingelandt, zoon uit een voorname Dordtse familie, in I649 als jonge valkenier die met zijn hond langs een rivier loopt, met een Torenvalk op zijn handschoen (afb. 8). De verwijzingen naar de jacht dienen uitsluitend om de status van de jonge Michiel, die in zijn fantasiekostuum niet echt op de jacht gekleed is, te accentueren. Een Torenvalk werd wel ingezet om kinderen te laten oefenen voor het jagen met een grotere valk. ${ }^{\mathrm{I}}$ 


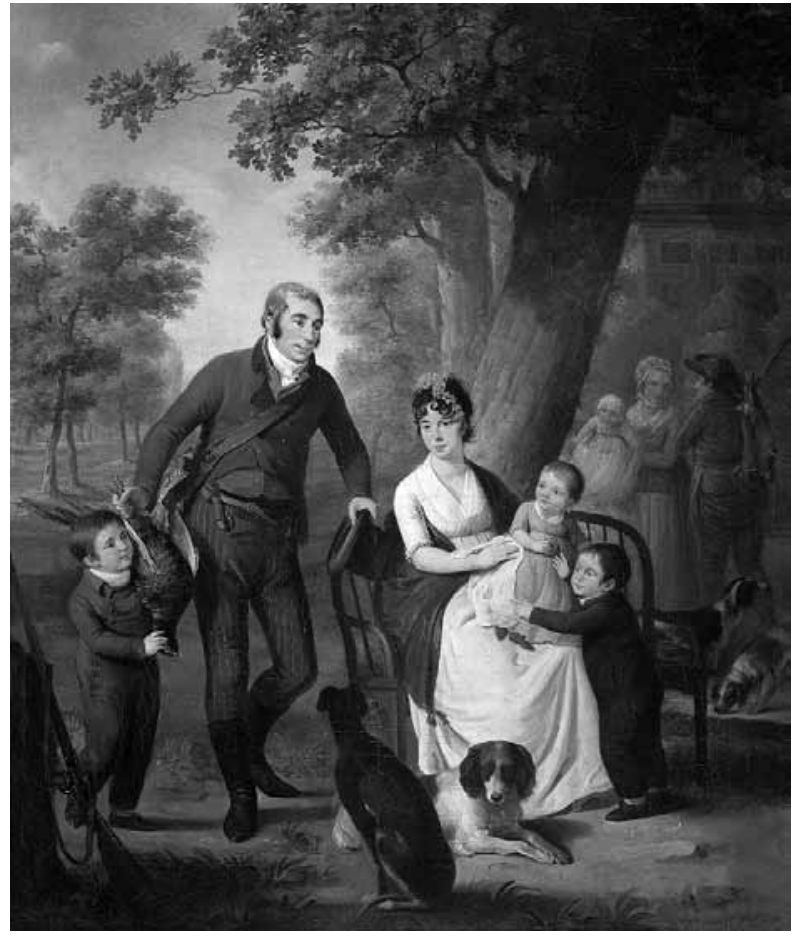

7 Adriaan de Lelie, 'Jhr. Gijsbert Carel Rutger Reinier van Brienen van Ramerus (1771-1821) met zijn vrouw en vier van hun kinderen', 1804, olieverf op doek, 84,5 × 70,5 cm. Bron: Rijksmuseum Twenthe, Enschede, inv. вR1380 (bruikleen Rijksmuseum Amsterdam, inv. SK-A-1355)

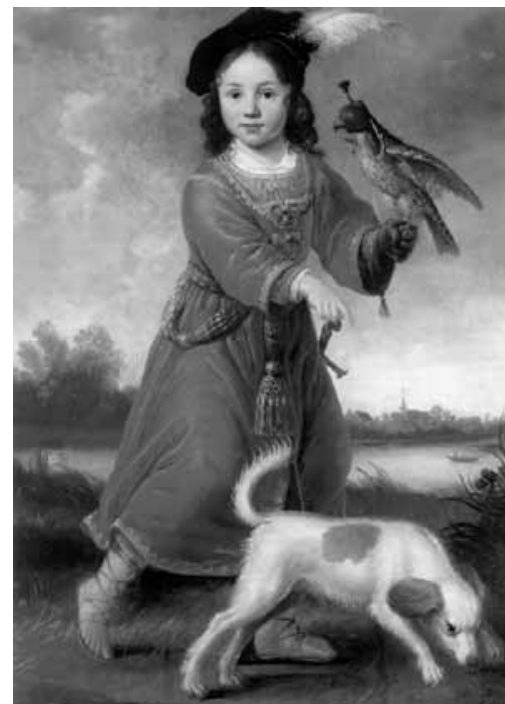

8 Jacob Gerritsz. Cuyp, 'Portret van Michiel Pompe van Slingelandt'.

(Zie kleurenkatern II, 4)

De terugkeer van de jacht werd aan het eind van de achttiende eeuw een thema in zowel de genre- als de portretschilderkunst. In portretten kreeg het een heel andere betekenis. Kwamen in een genrestuk anonieme jagers terug in huis met Patrijzen om de liefdesjacht te symboliseren, omstreeks I8oo lieten vooraanstaande personen zich portretteren terwijl zij, voorzien van bijvoorbeeld een Fazant, thuis of op hun landgoed terugkomen van de jacht. Weliswaar gaat het om een heel ander genre, maar visueel verschillen de typen voorstelling niet zoveel. De verschuiving is duidelijk: de achttiende-eeuwse jager keert terug bij vrouw en kinderen in de sfeer van huiselijkheid. Ook relatief nieuwe idealen betreffende natuurgevoel en buitenleven én status spelen een rol. De tijdgenoot zal bijvoorbeeld geen seconde Adriaan de Lelies portret van jonkheer Gijsbert Carel Rutger Reinier van Brienen van Ramerus met zijn vrouw en vier van hun kinderen (afb. 7) hebben geassocieerd met erotiek. De aanwezigheid van de 'onschuldige' kinderen, waarvan het jongetje nota bene de Fazant vastpakt, maakt een verwijzing naar lustgevoelens bij de ouders al heel onwaarschijnlijk. Het gezin Van Brienen van Ramerus toonde als burgers uit het goede hout te zijn gesneden. Van een algemeen-geldige moralistische boodschap was geen sprake. 


\section{Kunst, natuur, wetenschap}

De oude Nederlandse kunst kent twee vogelschilders bij uitstek: Melchior d'Hondecoeter en Aert Schouman. Hun werk is van hoge kwaliteit en verdient bijzondere aandacht.

\section{Hondecoeter}

Melchior d'Hondecoeter (I636-I695), geboren in Utrecht, kwam uit een ZuidNederlandse kunstenaarsfamilie die zich bezighield met het schilderen van landschappen en dieren. ${ }^{42}$ Hondecoeter werd opgeleid door zijn vader Gijsbert Gillisz. en, na diens dood in I653, door zijn oom Jan Baptist Weenix. In I659 vestigde hij zich in Den Haag, waar hij lid werd van de schildersconfrerie Pictura. In I663 vertrok hij naar Amsterdam om te trouwen met Susanna van Tradel; in I666 werd hun dochter geboren. Hoewel hij in zijn tijd beroemd was en goed heeft verdiend aan zijn schilderijen, stierf hij berooid.

Hondecoeter schilderde aanvankelijk illusionistische jachtbuitstillevens en pluimvee. In zijn stillevens werd hij beïnvloed door Jan Baptist Weenix en, na zijn verhuizing naar Amsterdam, door Willem van Aelst. Hij moet bovendien veel bewondering hebben gehad voor Frans Snijders: blijkens de inventaris van zijn nalatenschap bezat hij zeven schilderijen van deze kunstenaar. ${ }^{43}$ Hondecoeters pluimveestukken zijn dynamisch; de hoenders zijn in allerlei houdingen weergegeven en tonen zich op hun voordeligst. Er gebeurt van alles: de hanen, kippen en kuikens bekvechten onderling of worden door een roofdier of door andere vogels aangevallen - in een schilderij in het Louvre (Parijs) zelfs door twee Zeearenden, een in werkelijkheid onmogelijke situatie. Soms plaatste Hondecoeter zijn hanen en kippen, die vaak behoorden tot bijzondere rassen, niet op een boerenerf maar in een parkachtige omgeving. Hij herhaalde motieven zonder saai te worden en kwam in dit genre tot een aanzienlijke productie. Van een politieke of morele boodschap of van het gebruik van fabels, zoals in de schilderijen met hoenders van Snijders, is bij Hondecoeter voorzover bekend slechts incidenteel sprake. ${ }^{44} \mathrm{Hij}$ wilde aantrekkelijke, schilderachtige, gevarieerde voorstellingen creëren, ook als de ornithologische realiteit (zoals bij die Zeearenden) geweld werd aangedaan. Of Hondecoeter zelf vogels hield en kweekte is onbekend. 45

Werkelijk vernieuwend was Hondecoeter in zijn decoratieve parklandschappen met exotische vogels die, in een wereld vóór de televisieprogramma's van David Attenborough, een eye-opener moeten zijn geweest. Hij ontwikkelde dit genre tot grote hoogte. Deze vogelstukken vielen in de smaak bij de modebewuste welgestelden die ze plaatsten in grote stads- en landhuizen. ${ }^{46}$ Voorstellingen met dure exotische vogels onderstreepten de welvaart van de eigenaars. Zijn elegante vogeltaferelen pasten tegelijkertijd in de toenemende belangstelling voor de natuur zoals die blijkt uit de menagerieën, volières en 
naturaliënkabinetten die talrijke liefhebbers erop nahielden. ${ }^{47}$ Hondecoeter moet met zijn vogelstukken hebben willen bijdragen aan het inzicht in de schoonheid en variatie in de natuur, waarin zich de goddelijke wijsheid en scheppingskracht manifesteerden. Dit suggereert althans Arnold Houbraken:

'De mindere Schepsels [dan de mens] die in ontelbare getallen zig op het Waereldrond, in de lucht en de Wateren vertoonen, hebben meê hunne meer en minder schoonheid, in Stal en Koleur: en de Konstenaars, die de zelve natuurlykst en welstandigst hebben weten te verbeelden, hebben den grootsten roem behaalt, als in 't verbeelden der Wilde Dieren R. Savry en Jan Hendrik Roos. In Jachtdieren P. Snyers, en Ab. Hondius, [...]. In Vogelen Melchior de Hondecoeter, en Adriaan van Emont. [...] Welke alle en elk in 't byzonder natuurlyk en Konstig verbeeld, het oog des aanschouwers niet alleen verlustigen, maar de zelve ook verwondert doen staan over de menigvuldige veranderinge der Schepselen, en hunne verwonderbare verschillige samenstellinge hunner ledematen. ${ }^{4} 8$

Over Hondecoeters opdrachtgevers is niet bijzonder veel bekend. 49 Tenminste één ervan is gerenommeerd. Stadhouder-koning Willem iı bestelde voor veel geld werken bij Hondecoeter voor zijn drie residenties: Honselaarsdijk, Soestdijk en Het Loo..$^{\circ}$ Zo vervaardigde Hondecoeter omstreeks I678 voor Soestdijk De filosoferende ekster (afb. 9), voor Het Loo schilderde hij later Het drijvend veertje (afb. Io). In het privékabinet in Het Loo van Willem iı hing boven de schoorsteen het Landschap met uitheemse dieren waarop de menagerie van Honselaarsdijk - en niet, zoals lang is gedacht, die van Het Loo - is te zien..$^{\mathrm{I}}$

Hondecoeter was een meester in het schilderen van een rijke variatie aan levende vogels in de fraaiste kleuren en in natuurlijke houdingen. Hij schilderde ze losser dan zijn voorgangers en etaleerde meer (inter)actie tussen de die-

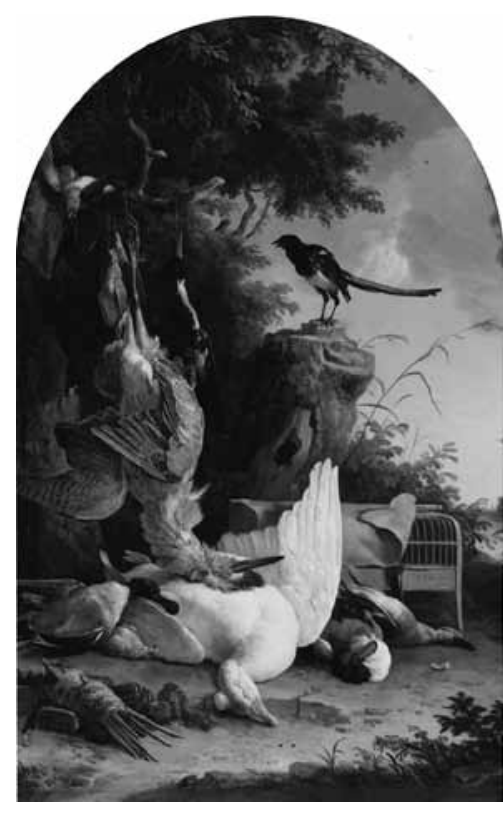

9 Melchior d'Hondecoeter, 'De filosoferende ekster', ca 1678. (Zie kleurenkatern II, 5)

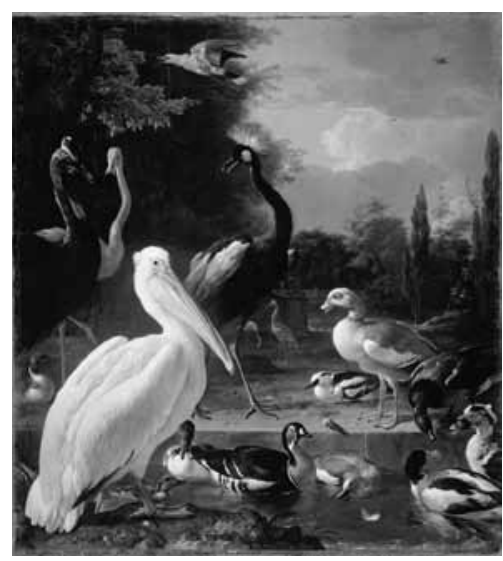

10 Melchior d'Hondecoeter, 'Het drijvend veertje', ca 1680. (Zie kleurenkatern II, 6) ren. Door de vogels op de voorgrond te plaatsen wonnen zijn taferelen sterk aan levendigheid. Voor doorkijkjes naar een achtergrond was daardoor minder ruimte. Een aardige suggestie, waar de kunstenaar zich over zou hebben verheugd, is dat Hondecoeters dieren zo zijn afgebeeld dat bijna gesproken kan worden van historiestukken met vogels in de hoofdrol..$^{2}$ De dieren schijnen zich in hun fantasiebiotoop thuis te voelen. De binnen- en buitenlandse vogels, 
meestal verenigd in één voorstelling, zijn vaak zo betrouwbaar weergegeven dat zij goed op soort en zelfs geslacht zijn te determineren.

De kunstenaar moet de meeste vogels, gelet op de nauwkeurigheid waarmee ze zijn weergegeven, hebben gezien: levend in de natuur en in volières of menagerieën zoals die van Willem ıı , of opgezet in naturaliënkabinetten, dan wel gedood in jachtpartijen of na vangsten. Zijn studie paste in een traditie die nog niet ten einde liep. ${ }^{3}$ Dat in zijn schilderijen vaak 'wilde' vogels en pluimvee door elkaar liepen zal geen eigentijdse toeschouwer hebben verbaasd. Dat gebeurde, afgaande op tekeningen en prenten, ook in menagerieën. ${ }^{44}$ Hoe Hondecoeter precies te werk ging is niet bekend; er zijn maar weinig geaquarelleerde of getekende studies van hem bekend. Toch moet hij, gezien de vele herhalingen in zijn werk, over een voorraad motieven hebben beschikt. Amusant is het verhaal dat kunstenaarsbiograaf Houbraken vertelt. Hondecoeter zou een haan hebben gedresseerd zodat hij stil bleef staan in alle gewenste houdingen. 55 De eerder geciteerde adviezen van Crispijn van de Passe tonen aan dat het 'tekenen naar levend model' door vogelschilders en hun volgers als probleem werd erkend.

Hondecoeter had tenminste één leerling, Willem van Royen, en diverse navolgers. De om zijn stillevens bekende schilder Adriaan Coorte ontleende verscheidene vogelmotieven aan Hondecoeters werk en Jan Weenix schilderde na I680 jachtbuitstillevens in zijn trant. Jacob van Oolen (ook Jan van Alen genoemd) kon volgens Houbraken Hondecoeters manier van schilderen zo goed navolgen dat de beste kenners het onderscheid niet zagen. Hierdoor kwamen er, aldus Houbraken, zoveel geschilderde 'Hanen en Hoenders' in de wereld dat de prijzen van echte Hondecoeters eronder te lijden hadden. Toch bleef onder kopers diens werk tot diep in de achttiende eeuw gewild..$^{6}$

\section{Schouman}

Vijftien jaar nadat Hondecoeter was overleden, werd zijn eigenlijke opvolger geboren in Dordrecht. Aert Schouman (I7IO-I792) woonde na zijn Dordtse leertijd tussen 1748 en 1753 afwisselend in Dordrecht en Den Haag, maar hij kwam ook regelmatig in Middelburg. Afgezien van een reis naar Duitsland (I753) en twee tochten naar Engeland (I765/66 en I775) bleef hij in Nederland. Hij schilderde genrestukken, portretten en bijbelse en mythologische thema's, maar vogels waren zijn fort. Schouman was vele jaren hoofdman en enkele jaren deken van de Haagse schildersconfrerie Pictura. Onder zijn leerlingen waren vogelschilders als Wouter Dam, Wouter Uiterlimmige, Gerrit Malleyn en Jabes Heenck. In Middelburg is zijn invloed herkenbaar in het werk van Abraham Meertens en Jacobus Perkois.

Schouman zou vele schilderijen met vogels - vooral kamerbehangsels - en meer dan 850 aquarellen en gouaches met vogels, andere dieren en planten vervaardigen. 57 Kamerbehangsels waren grote, wandvullende schilderingen 
op linnen die in vakken tegen een wand werden geplaatst. Bijbehorende deuren schoorsteenstukken en decoratieve pilasters completeerden de decoraties. Veel gegoede Nederlandse burgers lieten zo'n modieuze 'kamer in het rond' schilderen. Schouman ontwikkelde na I750 binnen het kamerbehangsel het vogelstuk. Zijn decoraties zullen hebben ingespeeld op achttiende-eeuwse sentimenten: men waande zich in zo'n omgeving in een paradijs op aarde. Het is verleidelijk te veronderstellen dat deze mode min of meer in de plaats kwam van de belangstelling voor het jachtbuitstilleven die in deze tijd op zijn retour was.

Schoumans behangselschilderkunst culmineerde in de vijfdelige serie voorstellingen met bijzonder fraai geschilderde exotische vogels en andere dieren in Nederlands aandoende landschappen voor Huis ten Bosch, die hij in I786 opleverde. Het grootste vak heet De menagerie van Prins Willem v op het Kleine Loo. Hoewel Schoumans schildering anders doet vermoeden, liepen de dieren in de menagerie niet vrij in een landschap rond.

Schouman kopieerde een van Hondecoeters werken in aquarel, bezat drie van zijn schilderijen en werd door diens werk geïnspireerd bij het schilderen van exotische en Europese vogels in parkachtige landschappen. Hij bracht, net als Hondecoeter, beweging in zijn voorstellingen doordat vogels werden opgeschrikt door andere vogels of door een hond. Er zijn meer overeenkomsten: beide schilders waren lid van de schildersconfrerie Pictura. Zoals Hondecoeter dieren in de menagerie van Willem in had bestudeerd, bezocht Schouman die van Willem v om er te tekenen en te aquarelleren. Maar Schoumans schilderstijl was losser dan die van Hondecoeter en hij was meer uit op een decoratief effect. Het landschap om de dieren heen is minder precies vastgelegd en wordt naar de achtergrond toe snel vager.

Hoe fraai Schoumans vogelbehangsels ook zijn, hij maakte werkelijk furore met zijn ornithologische aquarellen, waarin twee varianten zijn te onderscheiden. Er zijn compositiestudies van vogels in een parklandschap voor behangsels die aan toekomstige opdrachtgevers werden getoond (afb. II). Deze waren heel anders van karakter dan de aquarellen van één of meer vogels in een landschap, op de grond of op een tak (afb. I2). De laatste dienden als zelfstandig kunstwerk, of werden opgenomen in een reservoir waaruit Schouman naderhand bij het vervaardigen van kunstwerken kon putten. Schoumans vogelaquarellen werden gemaakt naar levende modellen in menagerieën en volières (en wellicht de vrije natuur) en, vaker, naar opgezette vogels in naturaliënkabinetten. De aquarellen met één of meer vogels op één tak zouden eens goed moeten worden vergeleken met de achttiende-eeuwse wijze van presenteren van opgezette vogels. Zij doen sterk denken aan de manier waarop bijvoorbeeld omstreeks I8oo in het Londense Leverian Museum vogels op takken in kasten werden getoond. ${ }^{8}$

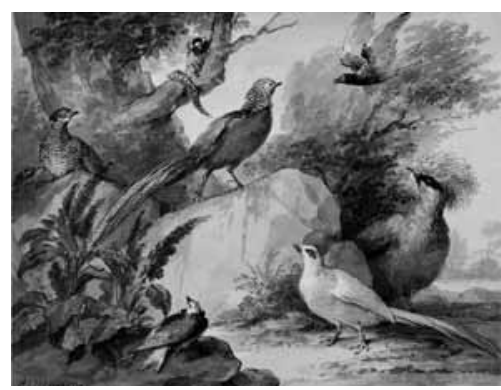

11 Aert Schouman, 'Vogelgroep in een landschap'. (Zie kleurenkatern II, 7) 


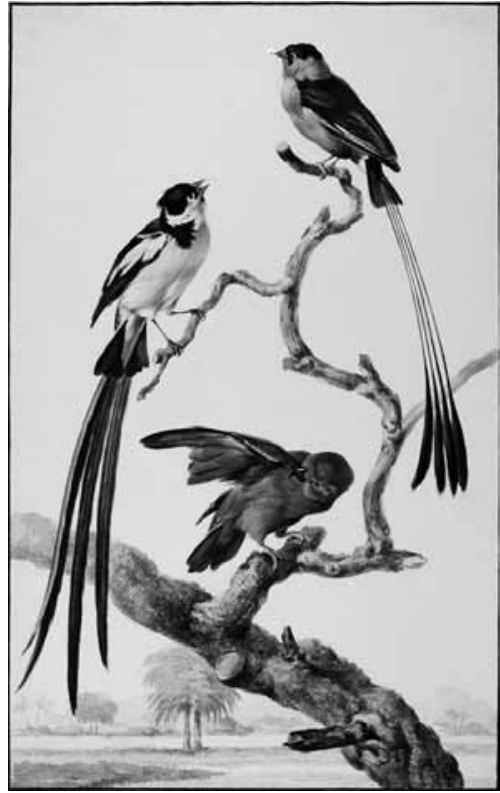

12 Aert Schouman, 'Drie vogels in een boom'. (Zie kleurenkatern II, 8)
Naar een aantal studies van vogels en andere dieren uit Willem v's menagerie bij Het Kleine Loo bij Voorburg werden gravures gemaakt voor het zogenoemde Regnum animale, het in de periode I766-1804 eerst in 24 losse deeltjes uitgegeven boek van de directeur van de menagerie, Arnout Vosmaer.59 Het is nog altijd van ornithologisch belang omdat diverse dieren er voor het eerst in werden beschreven. Deze uitgave was heel anders van karakter dan de eerste, eveneens fraai geillustreerde avifauna van Nederland, Nederlandsche vogelen; volgens hunne huishouding, aert, en eigenschappen van Cornelius Nozeman en Martinus Houttuyn (vijf delen; Amsterdam I770-I829). ${ }^{60}$ Met zijn voor wetenschappelijke publicatie bestemde tekeningen sloot Schouman aan bij een eeuwenoude kunstenaarstraditie. ${ }^{6 I}$ Wellicht voelde hij zich op grond van zijn wetenschappelijke werk een nieuw type geleerd schilder die op dit specifieke gebied waardering oogstte? Vanzelfsprekend moesten de kenmerken van de dieren goed herkenbaar zijn, maar Schouman slaagde er vaak op fraaie wijze in precisie aan artistieke losheid te koppelen.

De kunstenaar werkte, behalve in de menagerie van Willem $\mathrm{v}$ en in diens naturaliënkabinet in Den Haag, in diverse collecties van Nederlandse verzamelaars van naturaliën. ${ }^{62}$ In zijn ornithologische belangstelling moet hij affiniteit hebben gevoeld met de houders van menagerieën en kabinetten, zoals er in de achttiende eeuw in Nederland onder de welgestelde burgerij vele waren gekomen. ${ }^{63}$ Of hij in een van de bekendste menagerieën van zijn tijd, die van Blauw Jan op de Amsterdamse Kloveniersburgwal, heeft gewerkt is onbekend. Schouman moet analytisch hebben gedacht en - gezien ook zijn aantekeningen achterop de aquarellen - gewerkt als een liefhebber in de wetenschap en wellicht dezelfde motieven hebben gehad: natuurwetenschappelijke nieuwsgierigheid en onderzoek naar de openbaring van de Schepper in de natuur. ${ }^{64}$ Behalve voor Vosmaers uitgaven, gebruikte Schouman zijn vlotte dierstudies als basis voor uitgewerkte aquarellen en voor behangselschilderingen. ${ }^{65}$

Om zijn rijk geschakeerde, losse, transparante en kleurrijke aquarellen wordt Schouman meestal hoog gewaardeerd als een van de eerste echte Hollandse aquarellisten. Zijn werk, waarvoor hoge bedragen werden betaald, vond al tijdens zijn leven gretig aftrek. Vrijwel alle belangrijke Nederlandse verzamelaars van die tijd kochten aquarellen van vogels en zoogdieren van Schouman, een categorie die hoger werd gewaardeerd dan zijn bloemen en planten. ${ }^{66} \mathrm{Zo}$ bezat de Amsterdamse verzamelaar J. Danser Nijman een aantal kunstboeken (waarin tekeningen en prenten werden bewaard) met liefst 428 aquarellen van vogels, 48 van andere dieren en vijf 'vogelcomposities'. Deze indrukwekkende 


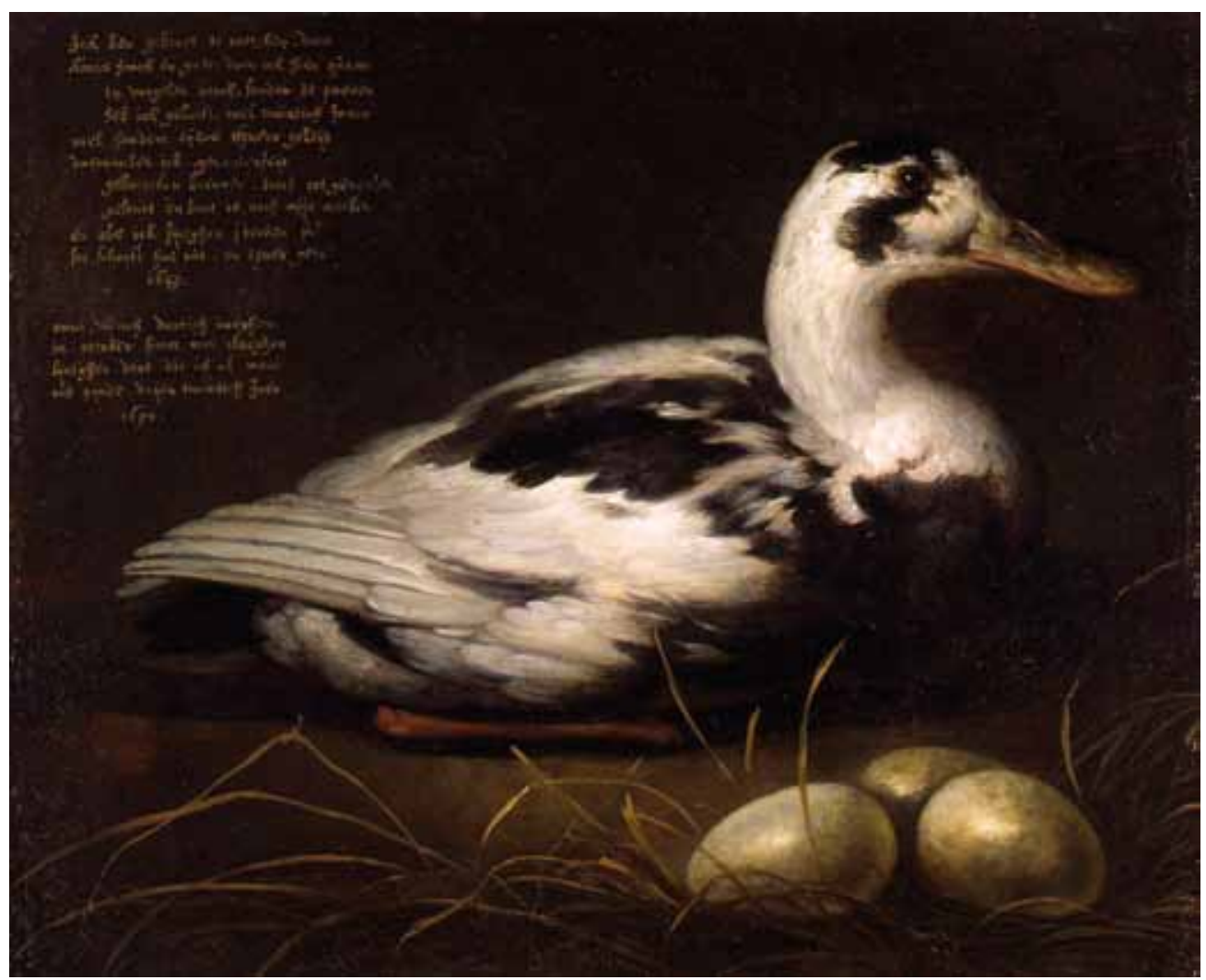

II, I

Aelbert Cuyp, Portret van de eend Sijctghen, 1647-1650, paneel, $35 \times 41,5 \mathrm{~cm}$.

Bron: Dordrechts Museum, Dordrecht (aankoop met steun van de Vereniging Rembrandt) 
162

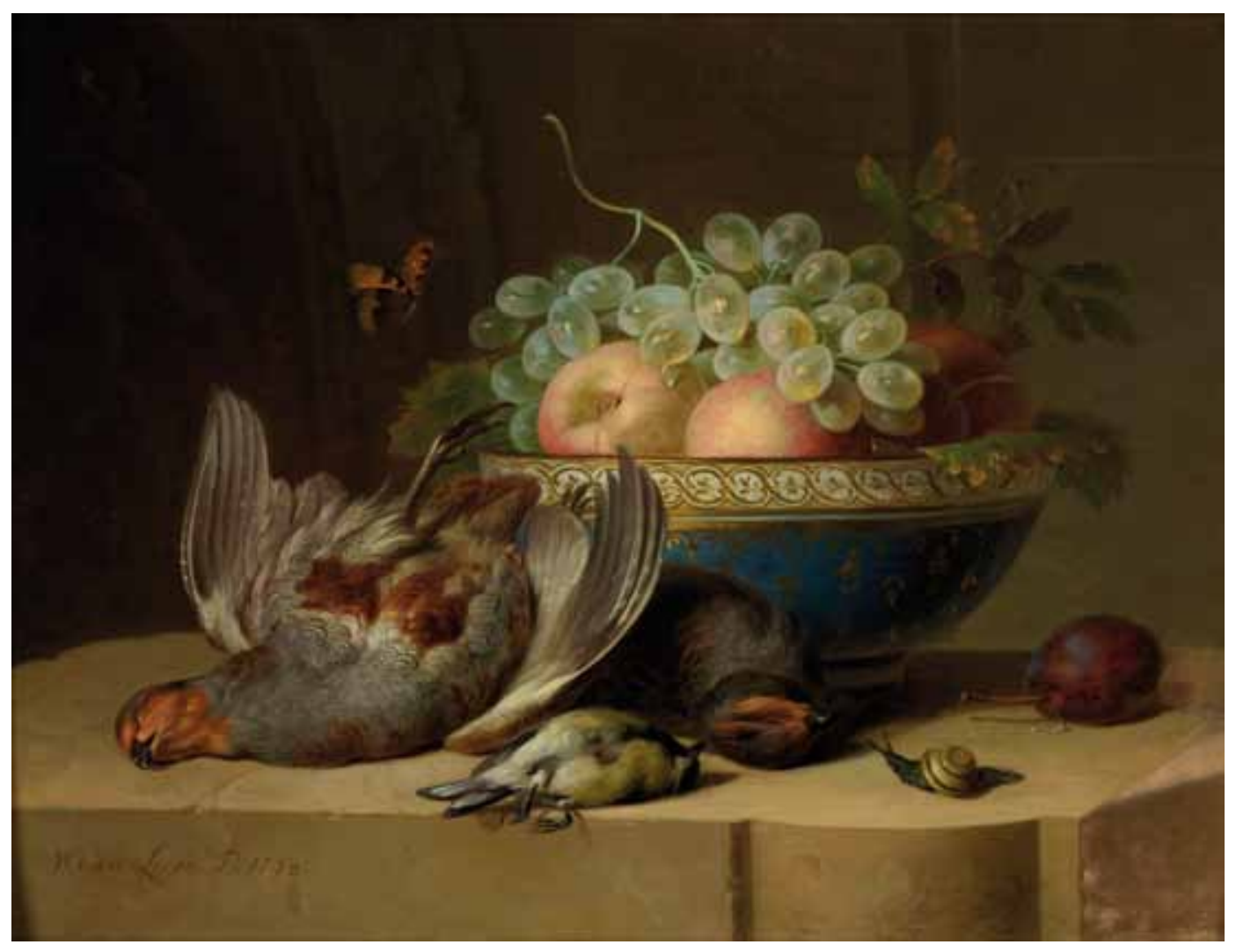

II, 2

Willem van Leen, Stilleven, 1798 , olieverf op paneel, 41,2 × 55,5 cm.

Bron: Rijksmuseum Twenthe, Enschede, inv. Br 329 (bruikleen Instituut Collectie Nederland, Rijswijk/Amsterdam) 


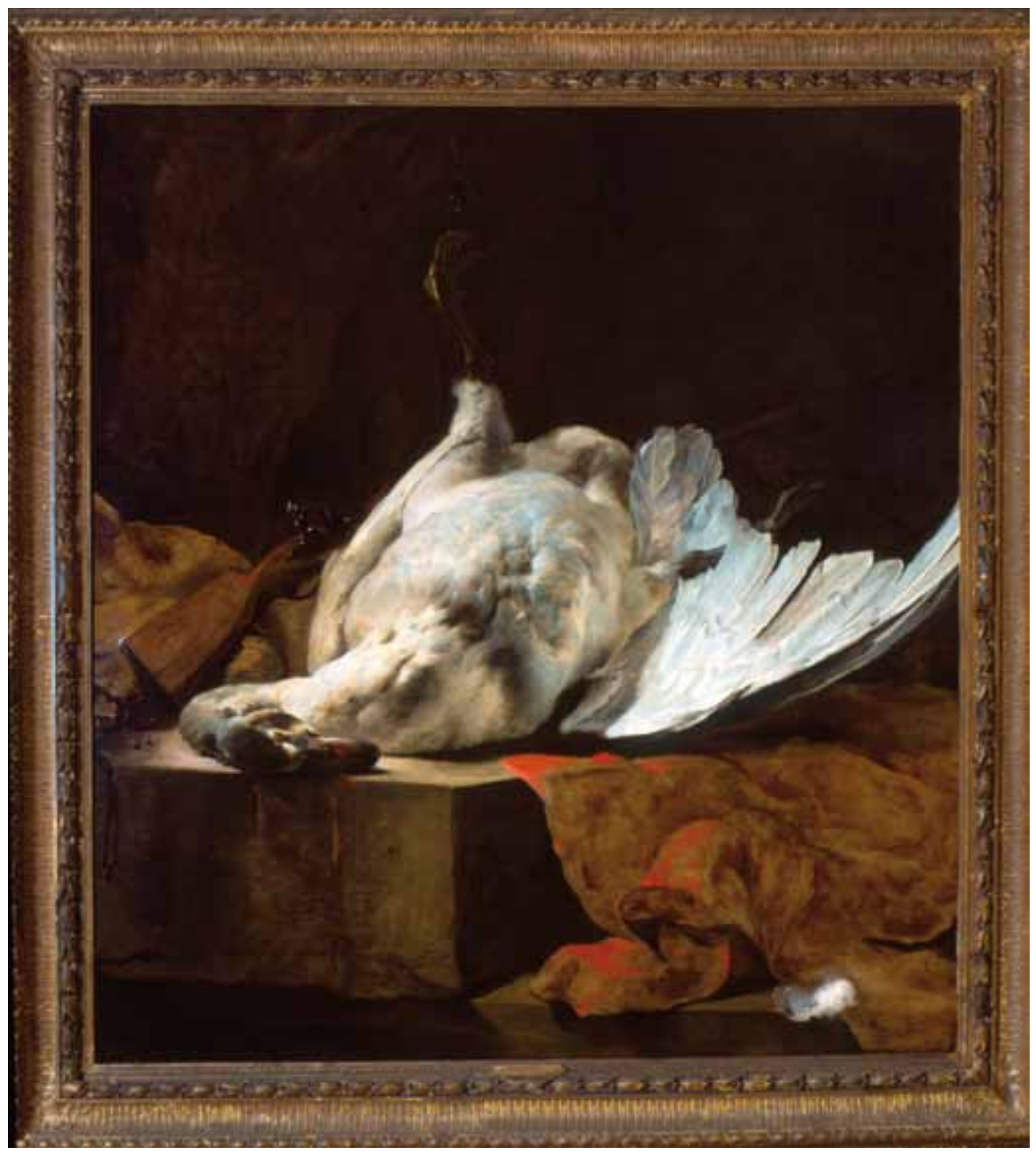

II, 3

Jan Baptist Weenix, Stilleven met een dode zwaan, circa 1651, olieverf op doek, 158,5 $\times 146 \mathrm{~cm}$. Bron: Museum De Fundatie, Heino/Wijhe en Zwolle, foto: Hans Westerink, Zwolle 


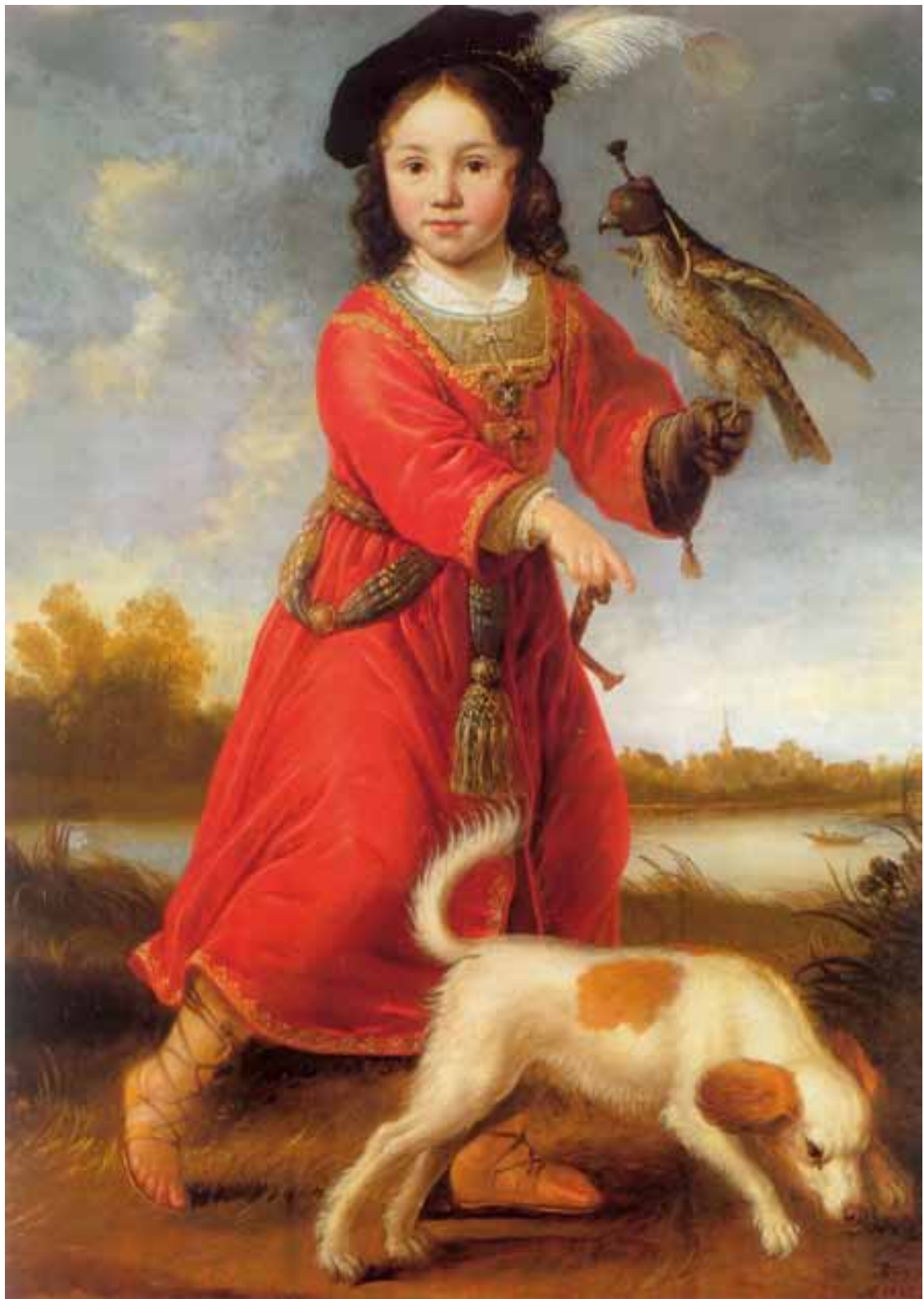

II, 4

Jacob Gerritsz. Cuyp, Portret van Michiel Pompe van Slingelandt, 1649, paneel, 106,2 x 77,8 cm. Bron: Dordrechts Museum, Dordrecht (bruikleen Instituut Collectie Nederland, Rijswijk/Amsterdam) 


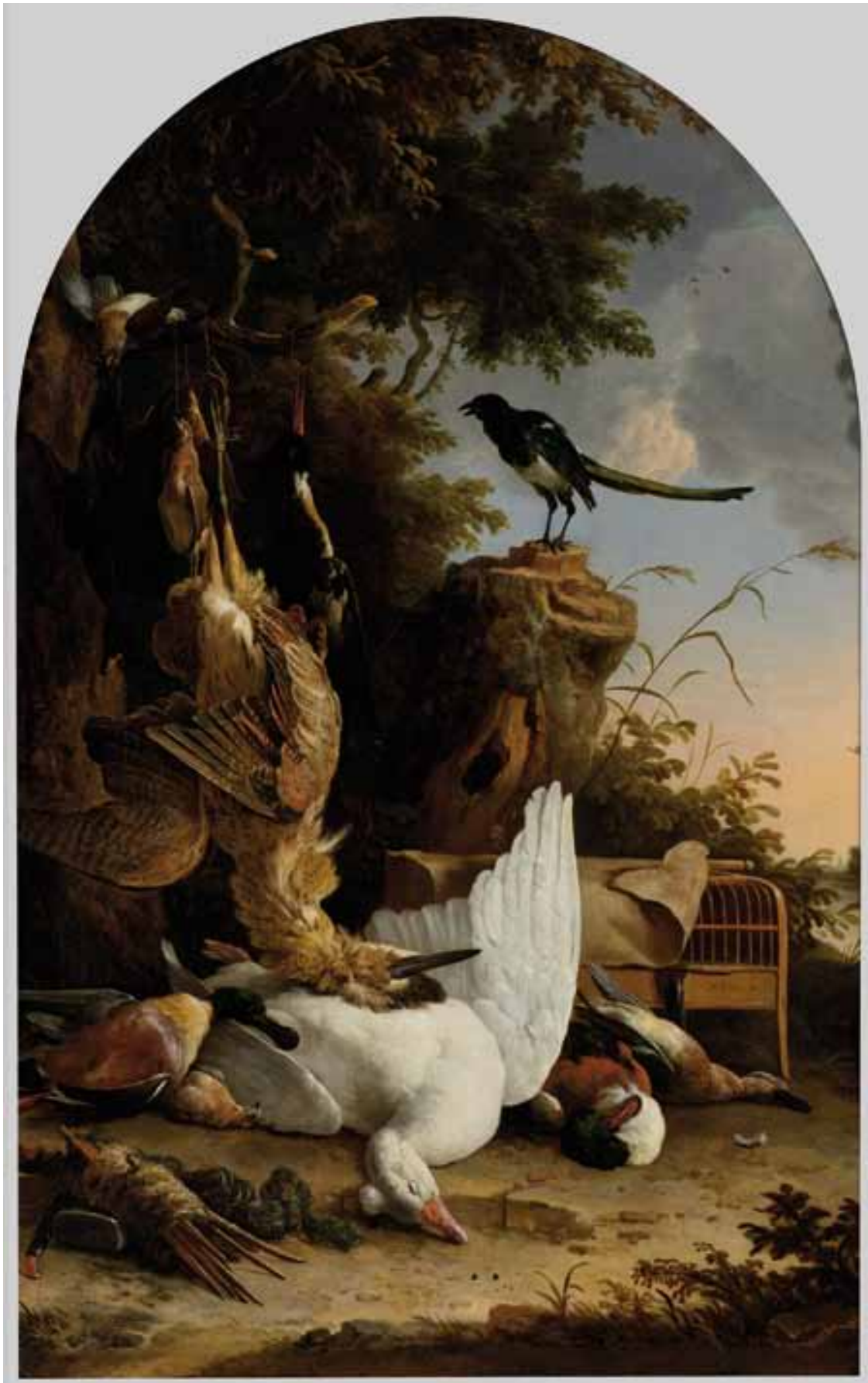

II, 5

Melchior d'Hondecoeter, Jachtbuit bij een ekster op een boomstronk, bekend als 'De filosoferende ekster', circa 1678, olieverf op doek, $215 \times 134 \mathrm{~cm}$. Bron: Rijksmuseum, Amsterdam, inv. SK-A-170 


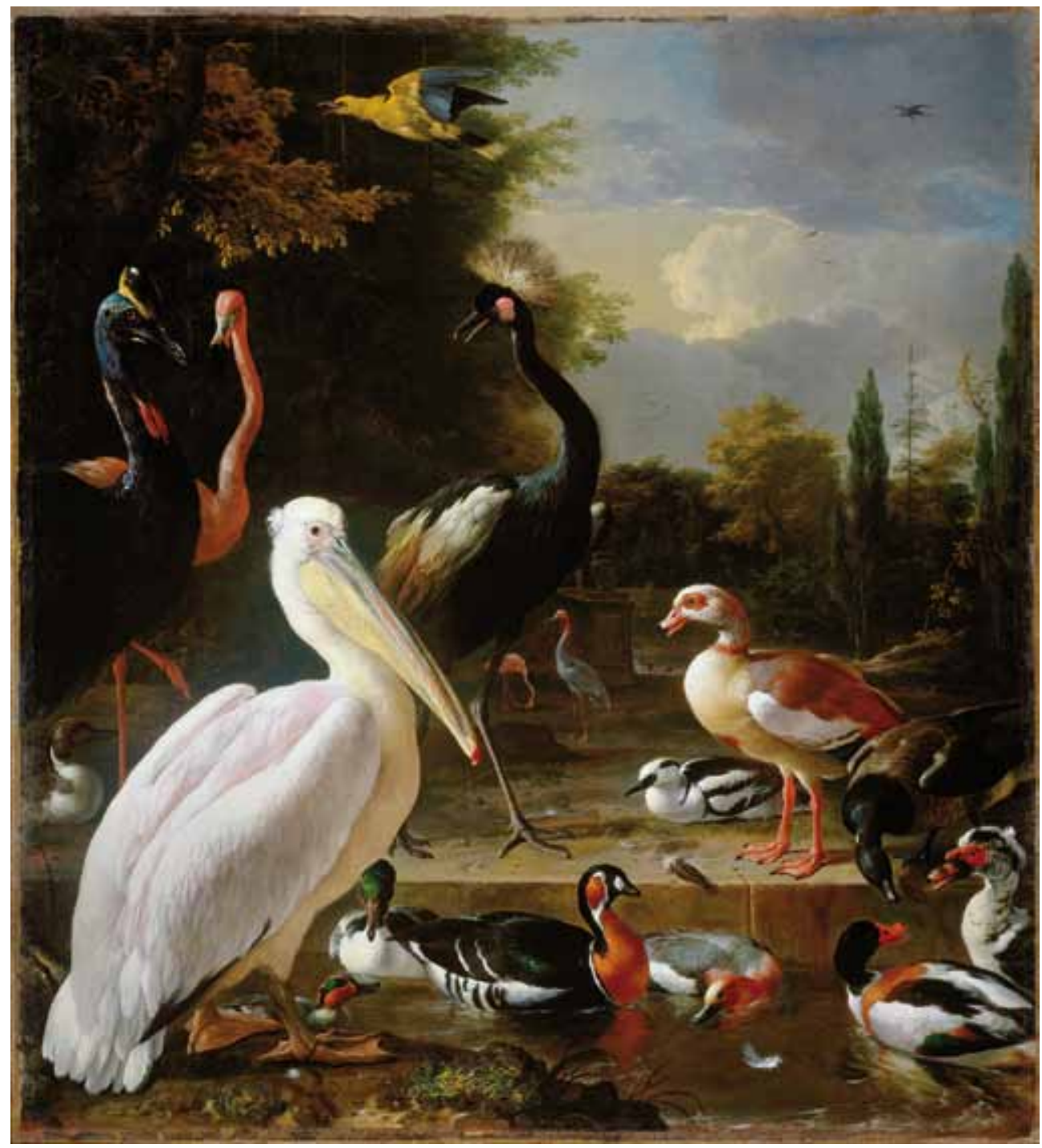

II, 6

Melchior d'Hondecoeter, Een pelikaan en ander gevogelte bij een waterbassin, bekend als 'Het drijvend veertje', circa 1680, olieverf op doek, $159 \times 144 \mathrm{~cm}$. Bron: Rijksmuseum, Amsterdam, inv. sK-A-175 


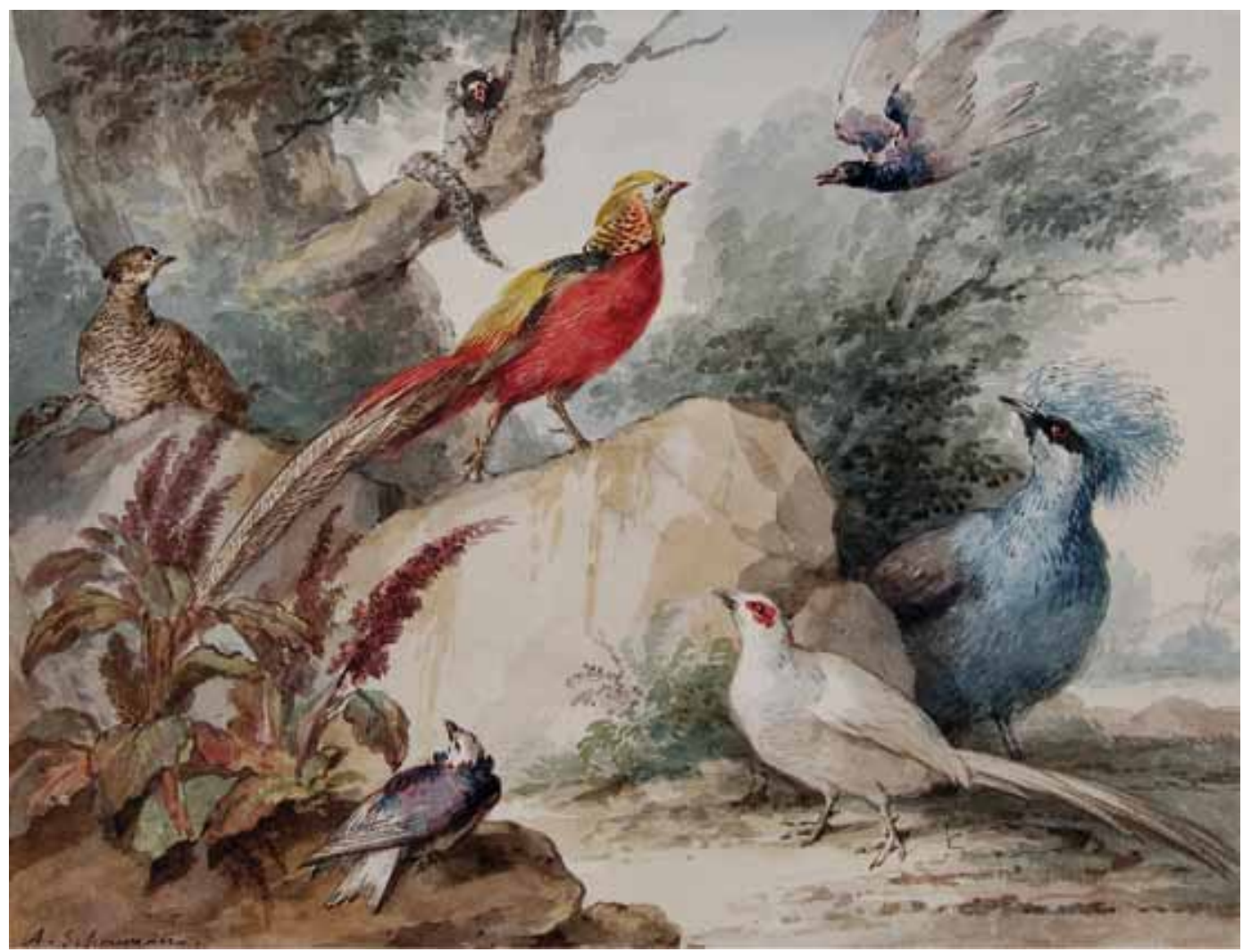




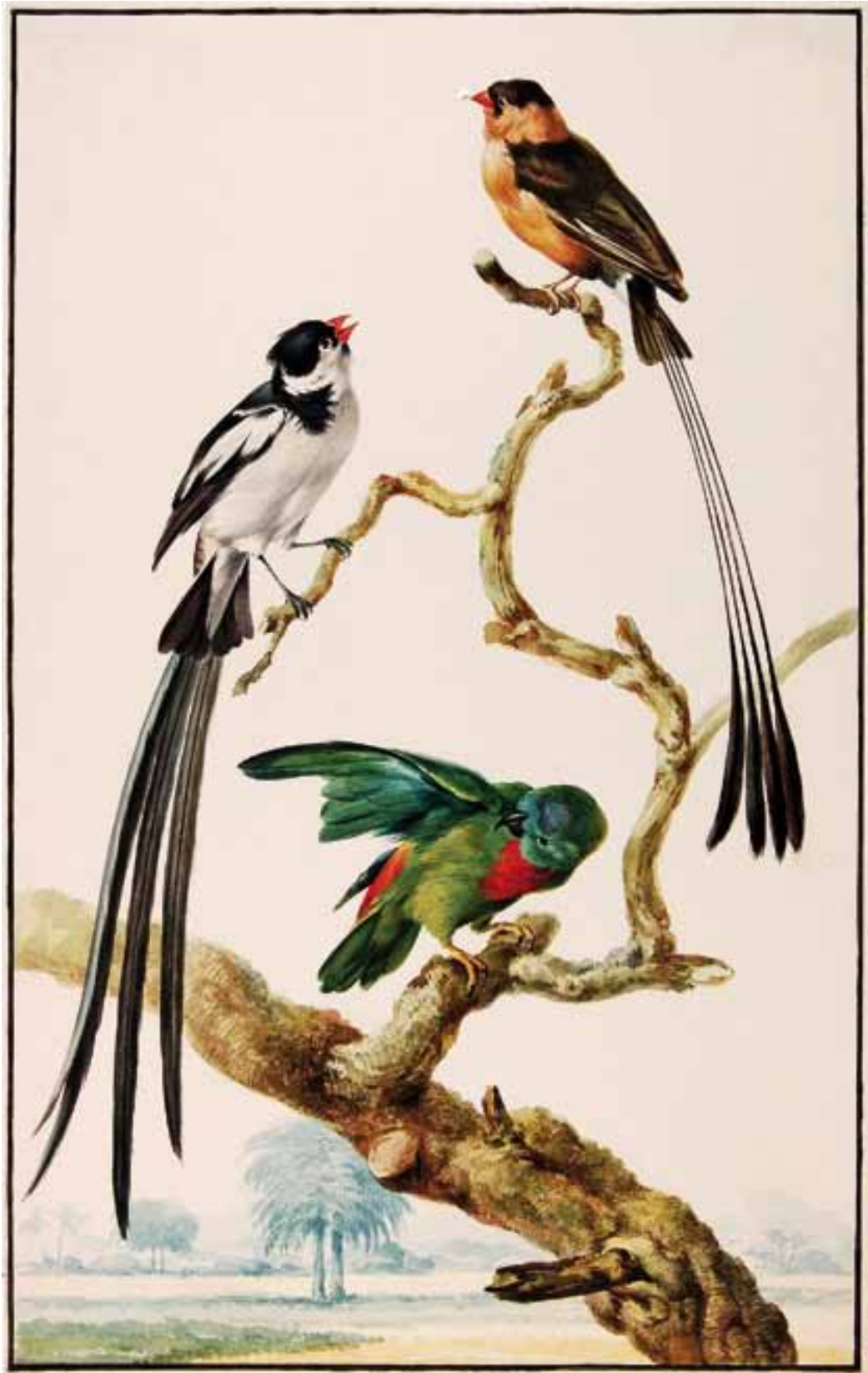

II, 8

Aert Schouman, Drie vogels in een boom, aquarel, 42,4 $\times 26,5 \mathrm{~cm}$.

Bron: Dordrechts Museum, Dordrecht (bruikleen Stadsarchief Dordrecht) 

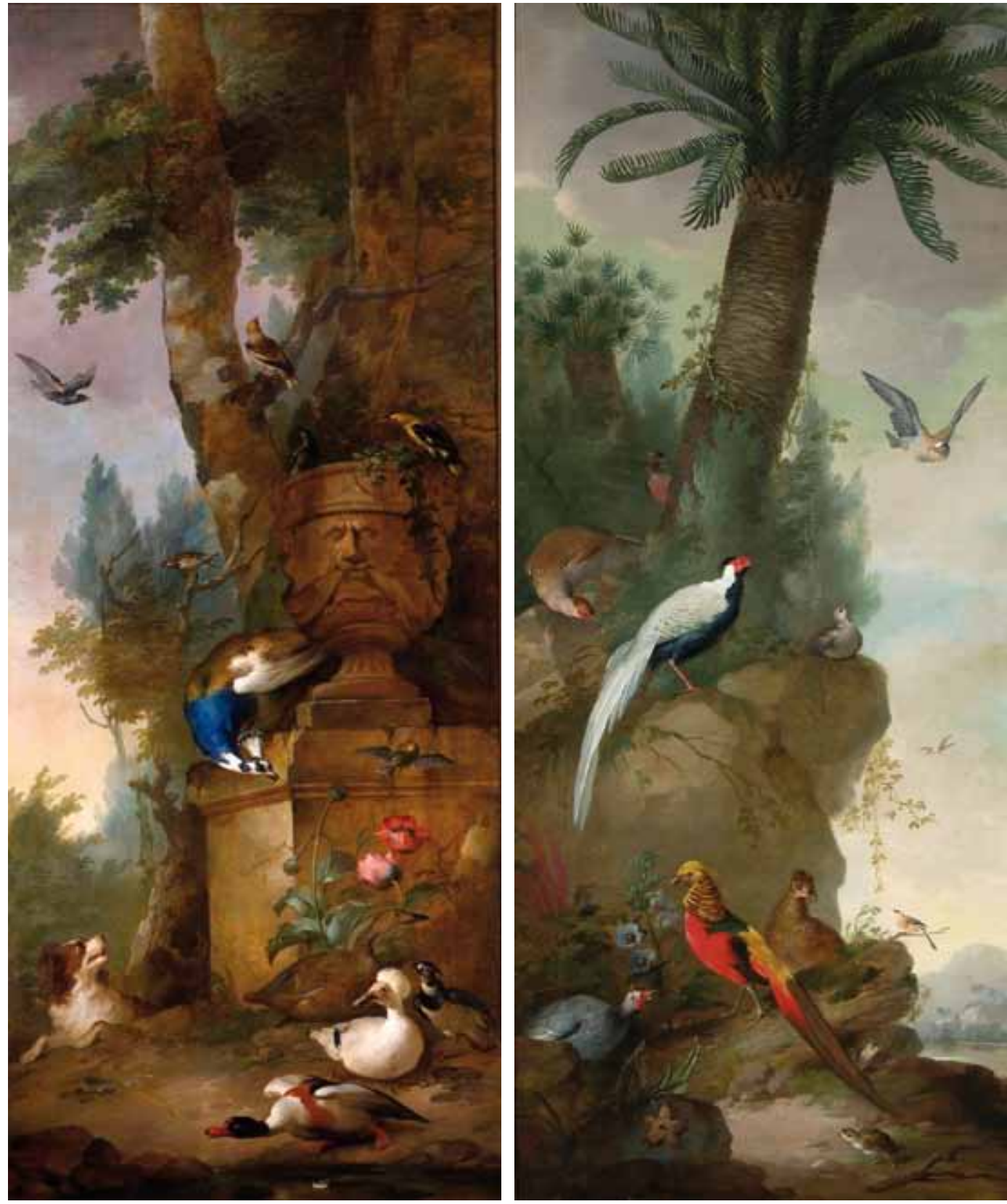

II, 9

Aert Schouman, Een pauw en eenden, opgejaagd door een hond, in een parkachtige omgeving, 1766, doek, $287 \times 123$ cm. Bron: Dordrecht, Dordrechts Museum (aankoop met steun van de Vereniging Rembrandt)

\section{II, IO}

Aert Schouman, Fazanten en andere vogels in een uitheems landschap, doek, $287 \times 123 \mathrm{~cm}$.

Bron: Dordrecht, Dordrechts Museum (aankoop met steun van de Vereniging Rembrandt) 


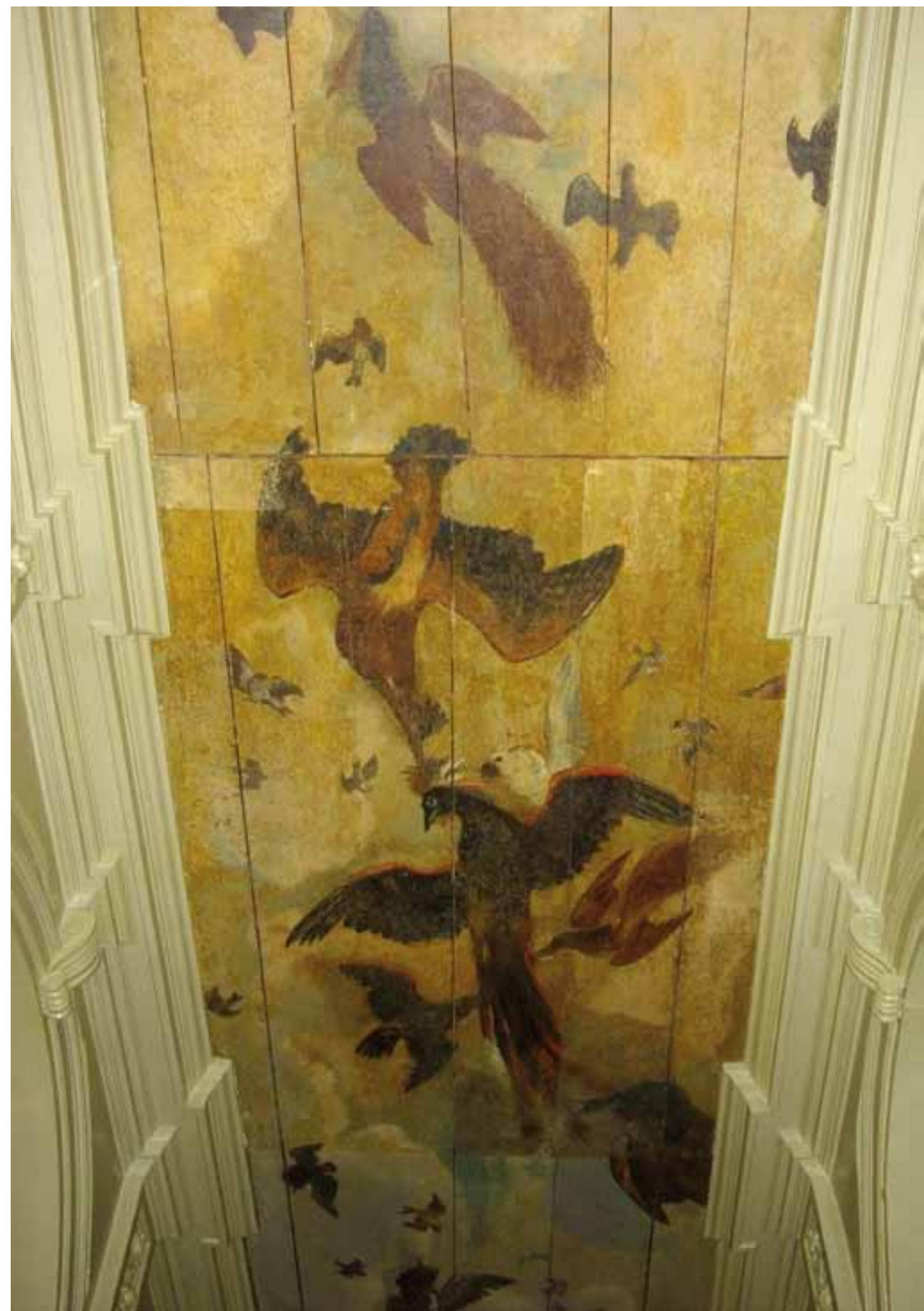

II, II

Valkenjachtplafondschilderingen KNAW/Trippenhuis, Amsterdam. Bron: foto Bart Hageraats 


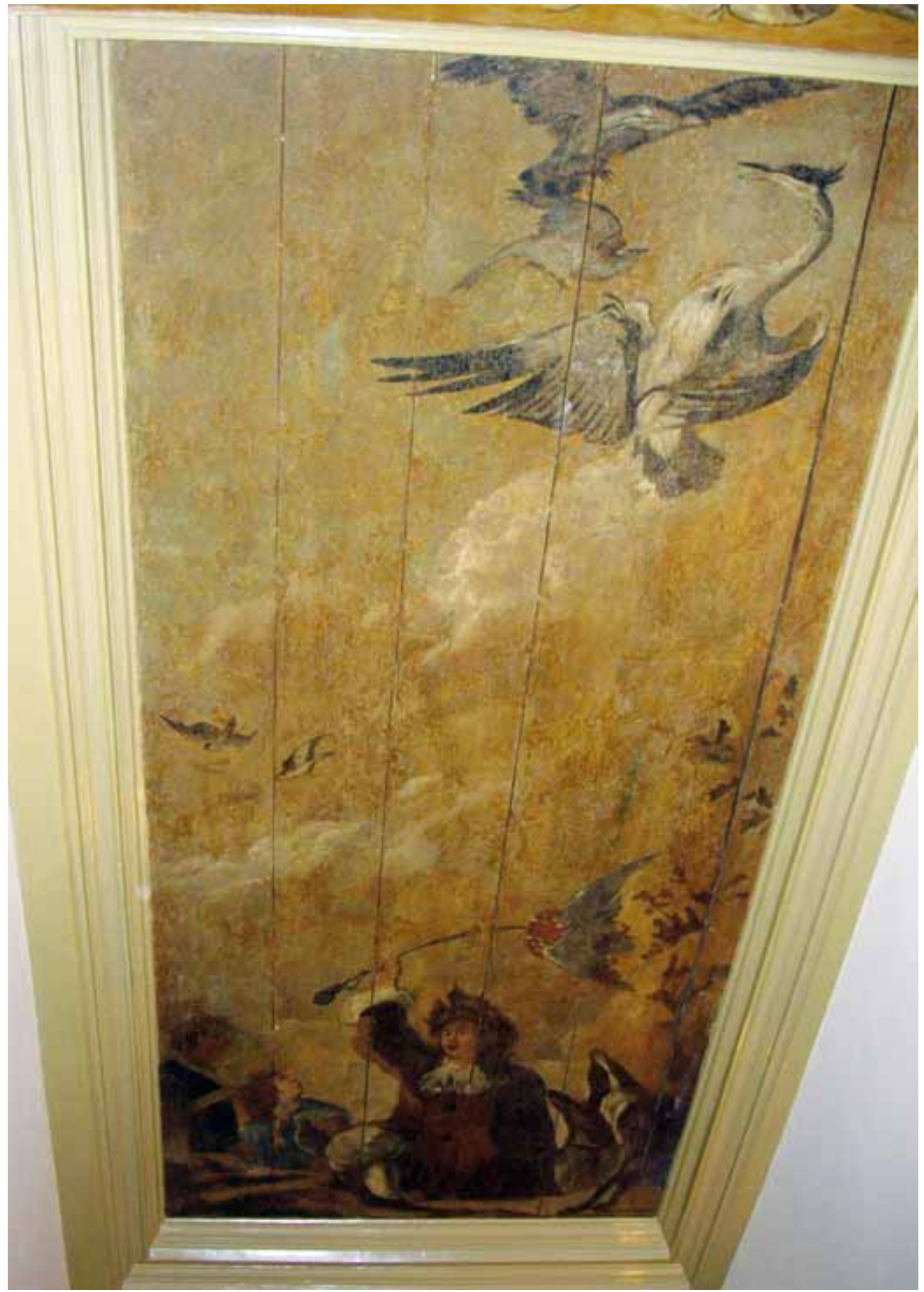

II, I2

Valkenjachtplafondschilderingen KNAW/Trippenhuis, Amsterdam. Bron: foto Bart Hageraats 


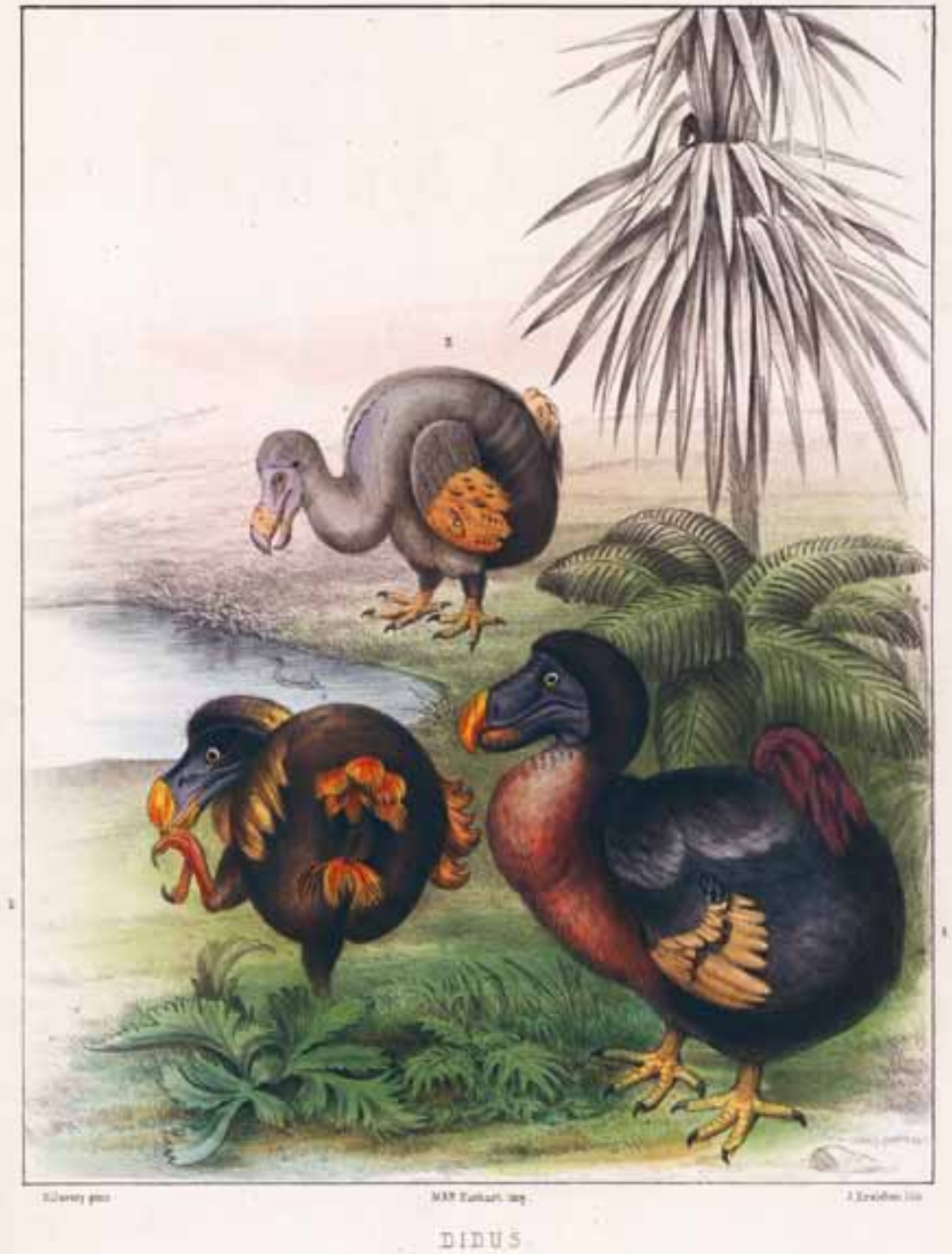

II, I3

Richard Owen f.r.s., Memoir of the Dodo (Didus ineptus, Linn.)., with an historical introduction by the late William John Broderip, f.r.s. (London 1866). Bron: KNAW-bibliotheek, IISG Amsterdam 


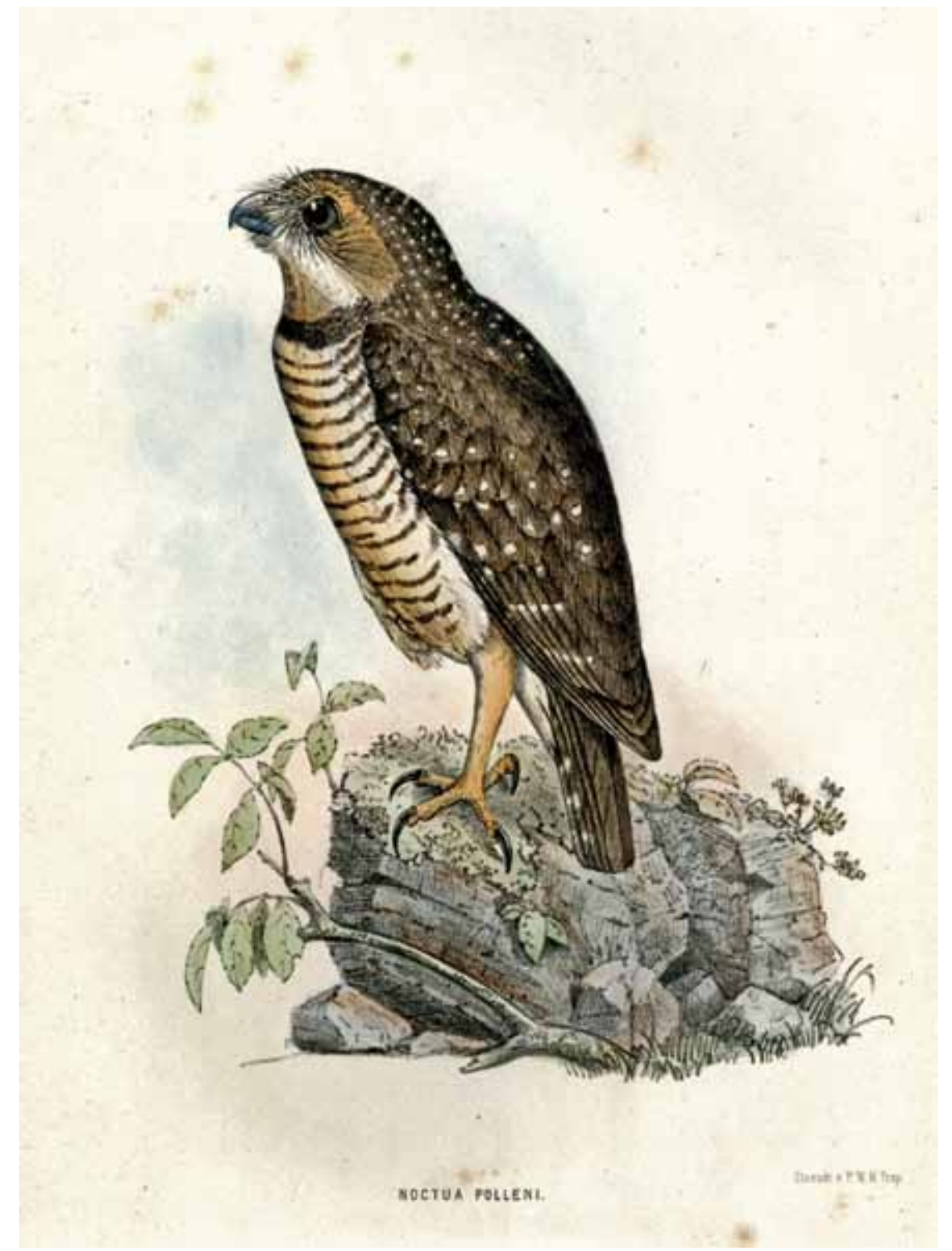

II, I4

Noctua Polleni, steendruk van P.W.M. Trap, in: M.H. Schlegel \& François P.L. Pollen,

Recherches sur la Faune de Madagascar, Leyde 1867-1868. Bron: KNAw-bibliotheek, IISG Amsterdam 


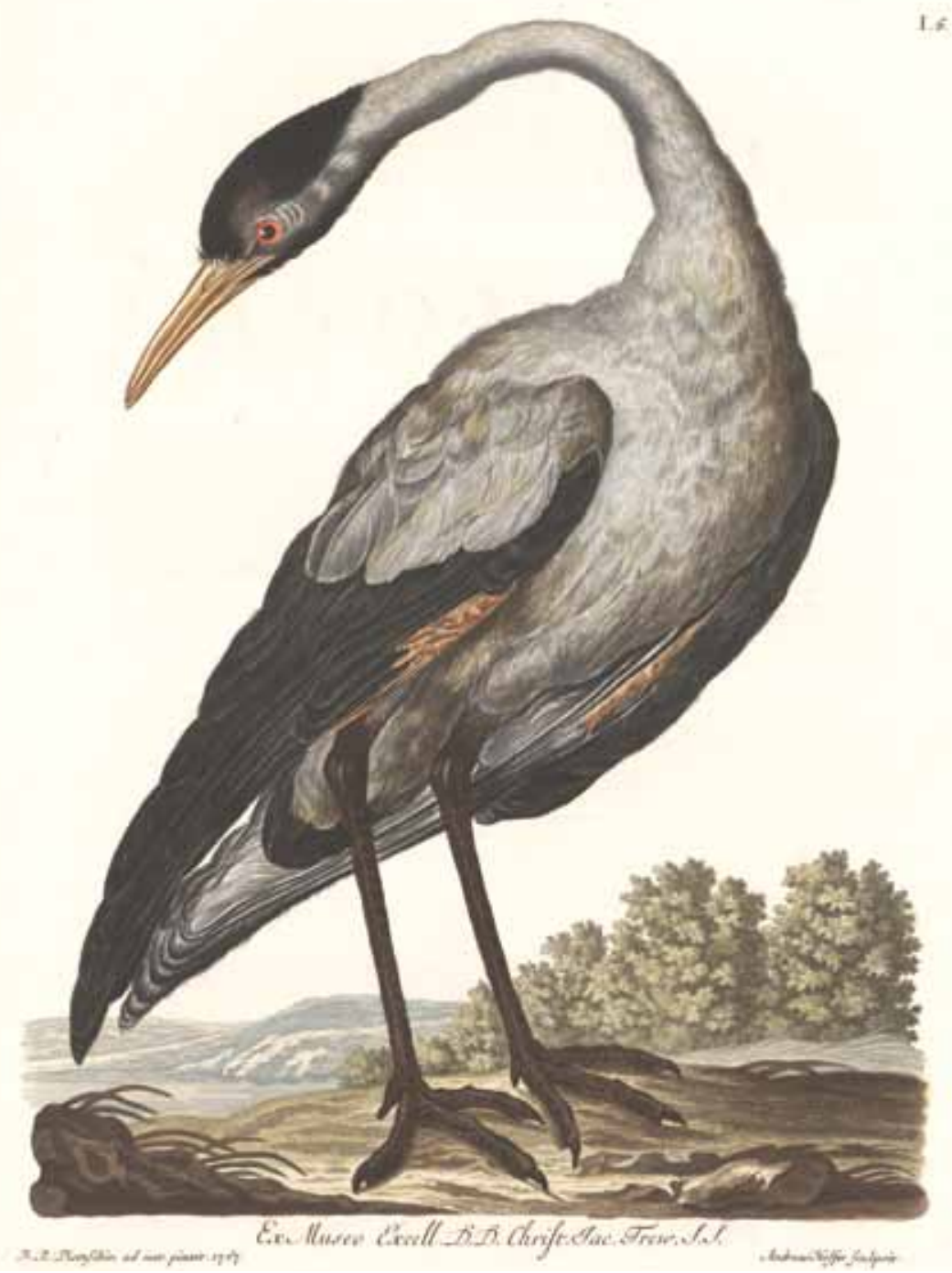

II, I5

Kraanvogel, uit 'Inleiding tot de historie der vogelen', in G.W. Knorr/vert. P.L.S. Muller, Deliciæ Naturæ Selectæ of uitgeleezen kabinet van Natuurlyke Zeldzaamheden van de Drie Rijken der Natuur (Dordrecht 1771) (zie hier afb. p. 28). Bron: KNAW-bibliotheek, IISG Amsterdam 


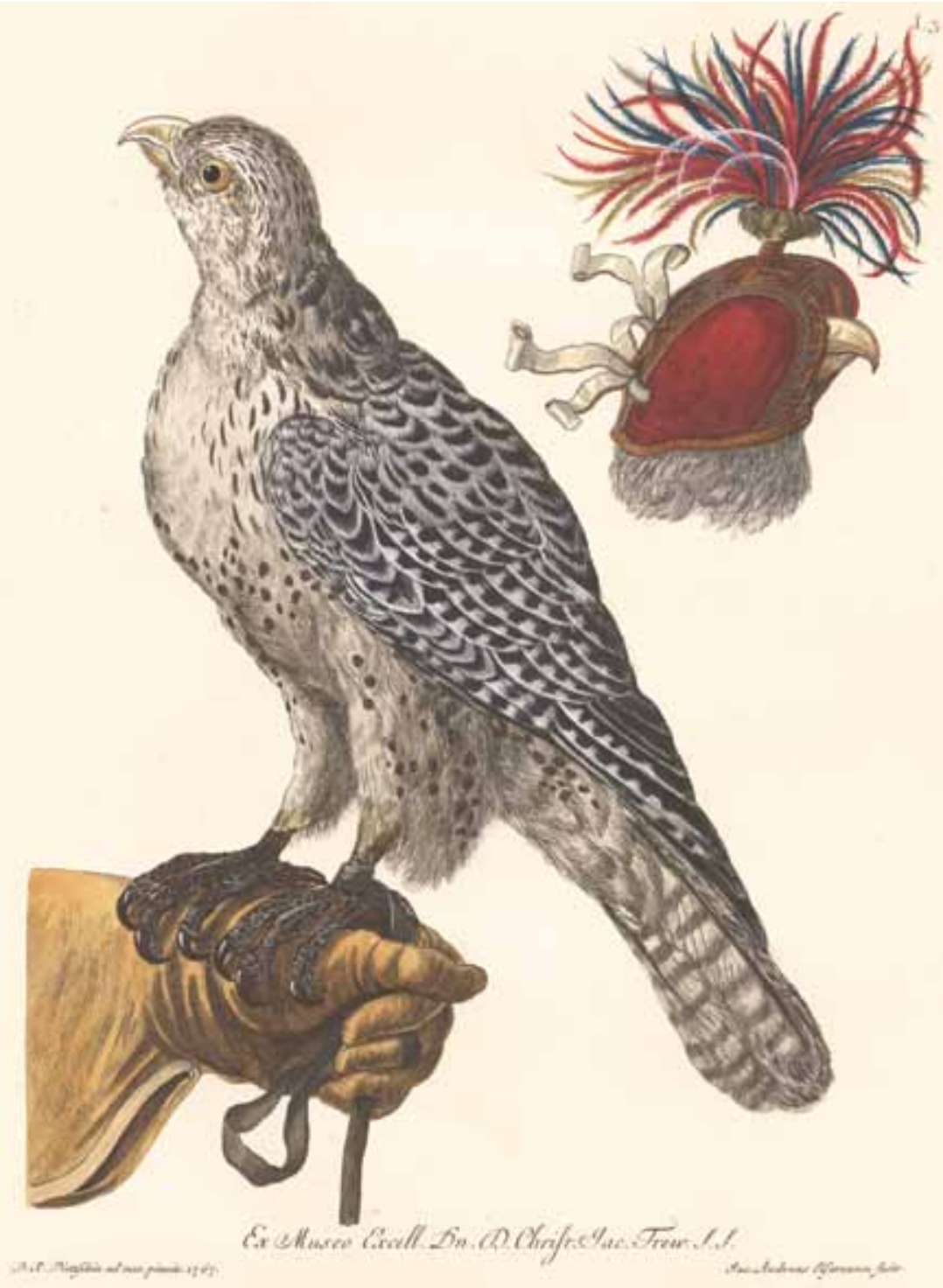

II, I6

Giervalk, uit 'Inleiding tot de historie der vogelen', in G.W. Knorr/vert. P.L.S. Muller, Deliciæ Naturæ Selectæ of uitgeleezen kabinet van Natuurlyke Zeldzaamheden van de Drie Rijken der Natuur (Dordrecht 1771) (zie hier afb. p. 28) Bron: KNAW-bibliotheek, IISG Amsterdam.

'Men ziet op deeze Plaat de afteekening van een Valk, die op de Hand van den Valkenier aan de Werp-Riem bevestigd, en met den Valken-Helm voorzien is. Zynde deeze Teekening byzonder wel getroffen. Waarschynlyk is deeze de Falco Nisus van den Heer Linnæus, en behoord onder den Rang der Havikken, waar toe deeze Vermaarde Autheur voormaals ook de Uylen, Valken, Arenden, Klaauwiers, Gier-Valken en Papegaaijen reekende, maar naderhand de Papegaaijen onder de Eksters plaatste, en verscheide andere Rangschikkingen in het Geslagt der Valken en Havikken maakte'. (Tekst bij Tab. 3, de giervalk) 


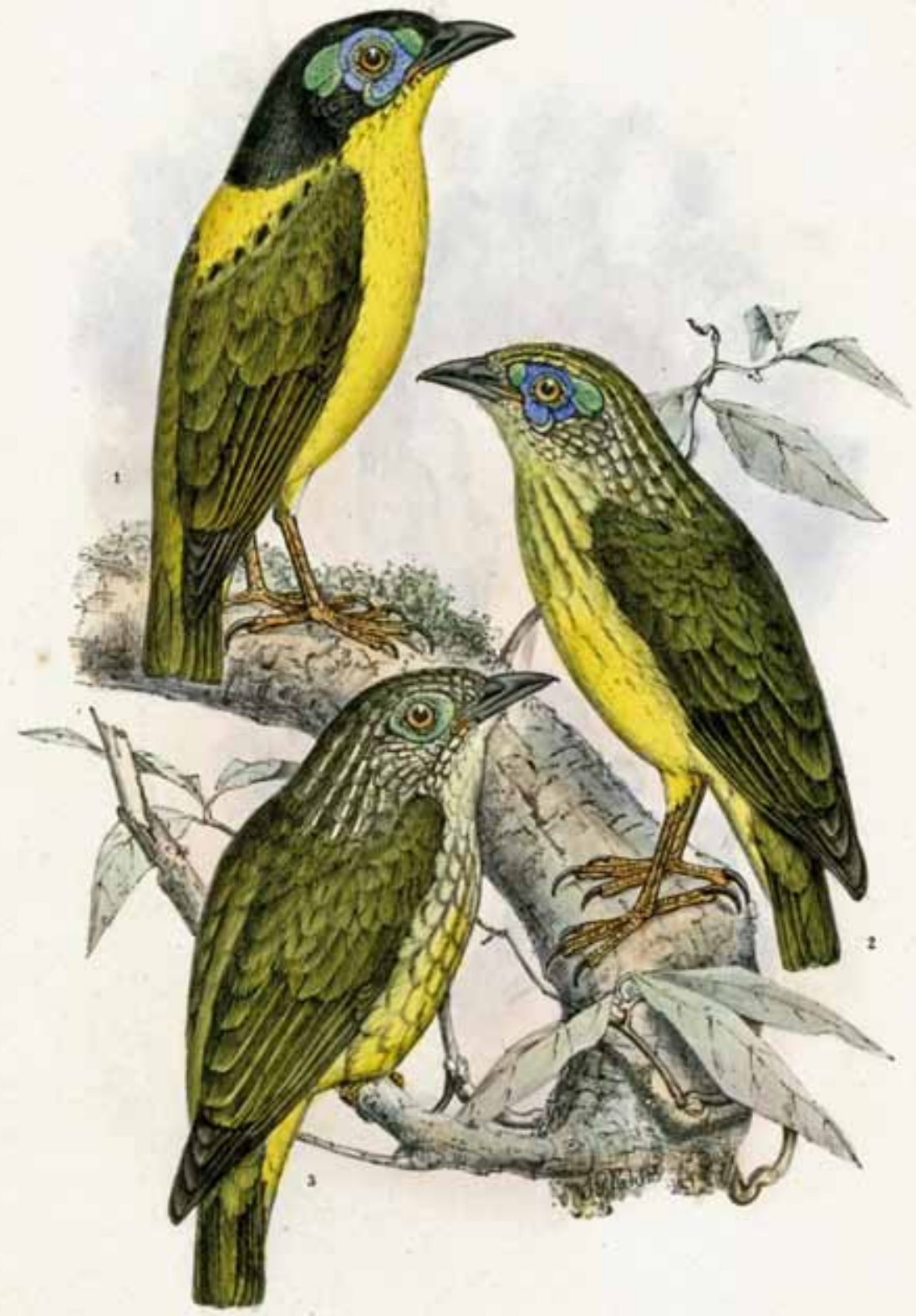

PHLECITA SCHLEET:

\section{II, I7}

Philepitta Schlegeli, steendruk van P.W.M. Trap, in: M.H. Schlegel \& François P.L. Pollen, Recherches sur la Faune de Madagascar, Leyde 1867-1868. Bron: KNAw-bibliotheek, IISG Amsterdam 
collectie werd geveild in I798.67 In de achttiende eeuw waren er opvallend genoeg, anders dan in de zeventiende eeuw, weinig verzamelaars van tekeningen die er tegelijkertijd een naturaliënkabinet op nahielden. Kennelijk was er sprake van een zekere specialisatie. ${ }^{68}$

Aan het begin van de negentiende eeuw karakteriseerden de kunstenaarsbiografen Roeland van Eynden en Adriaan van der Willigen Schoumans werk op een manier die een uitvoerig citaat waard is:

'In de vogels van Schouman bewondert men dan niet alleen de naauwkeurige breede, zachte en zeer gemakkelijke teekening, maar tevens ook de zoo levendige natuurlijke kleuren: wij zien als het ware de gouden puntjes en den heerlijken blaauwen glans op den prachtigen vederdos van den Paauw, de rijke en heldere kleuren van den Fazant, de onderscheidene soorten van Papegaaijen en den veelverwigen schitterenden gloed van de Eend of van de Duif; men verbeeldt zich het donzige der vederen te zien en alles is zonder de minst pijnlijke moeite dikwijls slechts luchtig aangewezen. Vele zijner Vogelen zijn van natuurlijke grootte afzonderlijk of bij paren afgebeeld, met eigenaardig bijwerk: als de streken, waarin zich de dieren onthouden, de takken, waarop de vogelen zitten en dergelijke. Hoe natuurlijk en bevallig zijn die achtergrondjes, door eene enkele hier en daar geplaatste penseel-streek, als spelende daargesteld. Insgelijks heeft men van hem keurig fraai geteekende ordonnantien, waarin men allerlei gevogelte in het water, op het land en in het geboomte ziet als dooreen wemelen en zweven of bij groepen zitten, in bevallige lust-

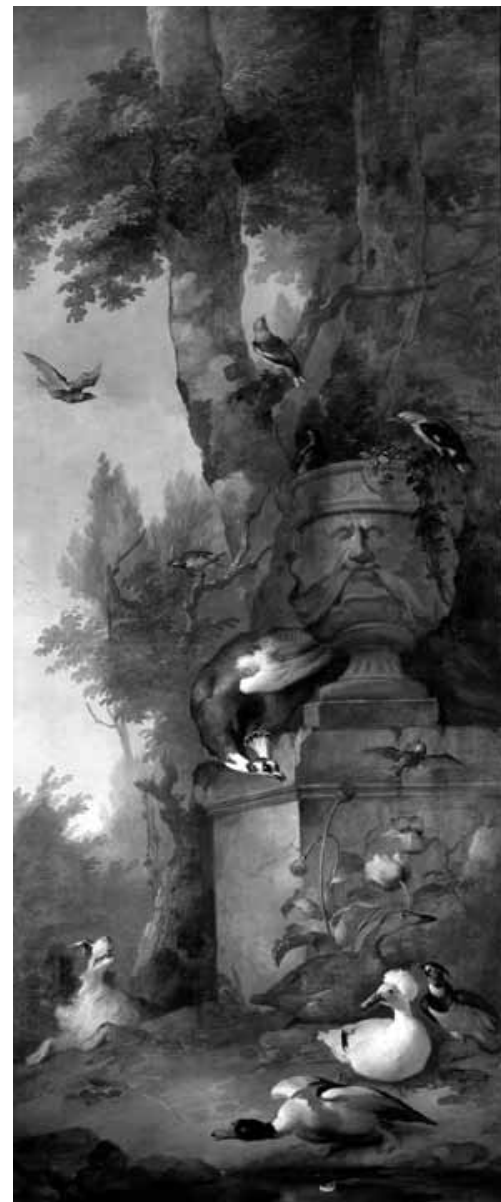

13 Aert Schouman, 'Een pauw en eenden, opgejaagd door een hond, in een parkachtige omgeving' 1766. (Zie kleurenkatern II, 9)

Niet alleen kunstliefhebbers, ook nationale en internationale biologen van zijn tijd, onder wie Thomas Pennant en Peter Simon Pallas, waardeerden zijn werk.70 Dit moet vooral zijn geweest om het natuurgetrouwe karakter van zijn vogels. In zijn mooiste aquarellen komen kunst, natuurlijke schoonheid en wetenschap volmaakt samen. Dat de landschappen waarin hij de vogels plaatste vanuit modern perspectief gezien nogal eens vragen oproepen, doet daaraan niets af. Fraai als ze vaak zijn, kloppen de landschappen veelal niet met de werkelijke biotoop van de desbetreffende vogel. Vaak heeft Schouman bij buitenlandse vogels een exotisch landschap gesuggereerd, soms combineerde hij Nederlandse soorten en die uit verre landen op een tak in een Dordts rivierenlandschap. Hij moet het landschap als een fraaie toevoeging hebben gezien die 


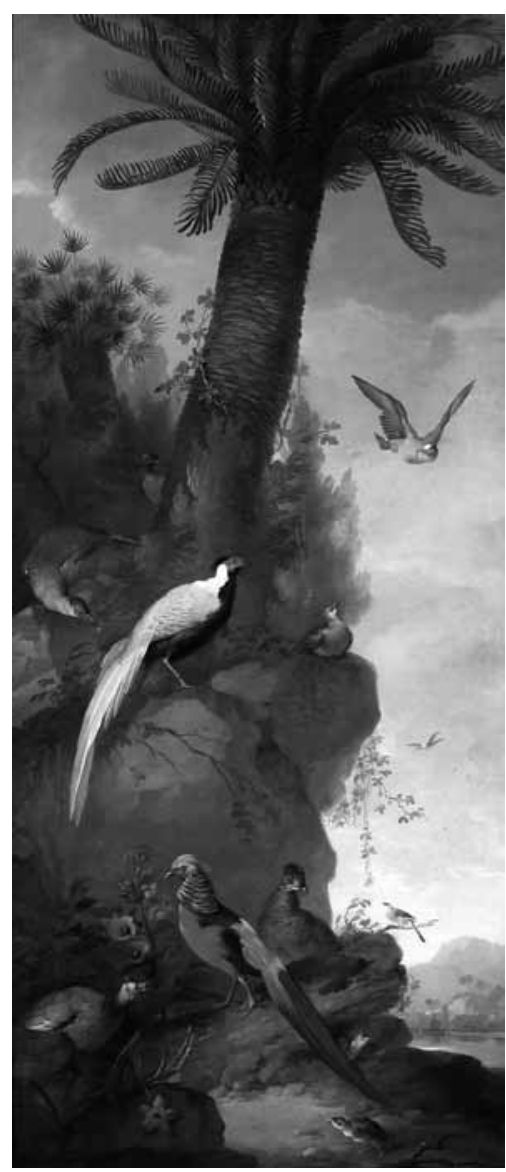

14 Aert Schouman, 'Fazanten en andere vogels in een uitheems landschap'.

(Zie kleurenkatern II, 10) weliswaar suggereert dat de afgebeelde vogels in vrijheid leefden maar die weinig extra informatie gaf over de (wél) betrouwbaar geschilderde vogels. Dat hij een achtergrond aantrekkelijk vond, blijkt ook uit het feit dat hij, volgens de catalogus bij de veiling van zijn nalatenschap uit I792, zelf landschappen aan aquarellen van andere kunstenaars als Johannes Bronckhorst en Pieter Holsteyn in zijn collectie toevoegde. ${ }^{\text {T }}$

Een vogelaar in de moderne betekenis geniet van Schoumans vakmanschap en ziet in diens werk opvallende combinaties. Zo schilderde de kunstenaar in een behangsel uit I753 Zomertortels, een Kemphaan, een Pestvogel, waarschijnlijk een Groenling en een kalkoen met kip en kuikens op het erf van een boerderij.72 Afgezien van de voor een wilde Kemphaan wel héél onwaarschijnlijke biotoop, is het samengaan van Zomertortels (laat arriverende zomervogels) en Pestvogel (wintergast) in werkelijkheid onmogelijk. Schouman moet als kenner bewust een keus voor de esthetiek hebben gemaakt, ten koste van de biologische betrouwbaarheid. De kunstenaar suggereert een vrije, idyllische natuur die ver afstond van de werkelijkheid in menagerieën, waar de meeste dieren achter afzettingen en in hokken en volières leefden. Hij sloot zo aan bij een oude beeldtraditie in de grafiek, zoals de bekende dierenprenten van Adriaan Collaert.73 Kunstenaars creëerden hun eigen werkelijkheid. Bij Schouman geen zingende vogels in hun eigen territorium.

Dergelijke observaties zijn ook mogelijk bij twee bewaard gebleven Zeeuwse behangsels. Schouman vervaardigde in I766 voor een Walchers buitenverblijf, het Huis te Oostkapelle, een fraai omvangrijk ensemble van vijf vogelbehangsels dat na allerlei omzwervingen in 1996 door het Dordrechts Museum werd verworven (afb. I3 en I4). Van de bijbehorende behangsels zijn alleen foto's bewaard. ${ }^{74}$ De vogelaar bewondert de nauwkeurigheid waarmee het verenkleed van iedere soort is afgebeeld. Hij ziet wild in Nederland voorkomende vogels als Eider, Bergeend, Kievit en Wielewaal naast geïntroduceerde Aziaten als pauw en Goudfazant en merkt op dat de houdingen, de soms wat vale kleuren en het ingevallen uiterlijk van de vogels er onnatuurlijk uitzien, zoals men verwacht bij schilderingen naar opgezette vogels. De interacties doen gemaakt aan. Vond men in die tijd dat vogels er op deze manier natuurgetrouw uitzagen? Hij ziet verder het vrouwtje Eider, buiten het kustgebied altijd al een zeer schaarse verschijning, in een onmogelijke leefomgeving.75 
Hoewel Hondecoeter en Schouman uitblonken in vogeltaferelen waren zij, zo bleek al, niet de enige Nederlandse vogelschilders van hun tijd. Opvallend genoeg ziet het ernaar uit dat er locale concentraties voor de beoefenaars van dit genre waren, zoals in Middelburg. In Hoorn leefden omstreeks I700 drie pasteibakkers die tegenwoordig bekender zijn om hun vogelaquarellen: Johannes Bronckhorst, diens leerling Herman Henstenburgh en Henstenburghs zoon Anton. De fraaie bladen in dek- en waterverf met vogels, insecten, bloemen en vruchten van vader Henstenburgh, die zijn eigen pigmentrecepten ontwikkelde, waren bij Nederlandse verzamelaars zeer geliefd. ${ }^{6}$ Het zijn slechts drie van de vele dilettanten die op hoog niveau dieren in gouache of waterverf schilderden. Sommige van hen brachten naturalia bijeen of zetten vogels op en kwamen van daaruit tot de schilder- en tekenkunst. Al aan het begin van de zeventiende eeuw zette Adriaan van Utrecht, die ook vogels schilderde, 'alle soort van pluimgedierte' zo knap op 'dat de dieren schenen te leven, en veel gekogt wierden om op Kabinetten te zetten.' 77 Omstreeks I8oo was Jan Hendrik Nicolay uit Leeuwarden liefhebber van vogels; hij zette ze op voordat hij tot het schilderen ervan overging. Hij presenteerde zijn 'dood en levend Gevogelte' op tenminste vijf tentoonstellingen van levende meesters. ${ }^{78}$

\section{Wind onder de vleugels}

Vogels speelden gedurende een belangrijke periode in de geschiedenis van de Nederlandse schilderkunst een veelzijdige rol. Ongetwijfeld werden kunstenaars en publiek toen al gegrepen door hun soms exotische schoonheid, levendigheid en vliegvermogen, al zullen liefhebbers van jacht en culinaire genoegens de dieren met een ander oog hebben bekeken. Deze excursie in sneltreinvaart door een uitgebreid gebied maakt duidelijk dat vogels in de zeventiende en achttiende eeuw op vele manieren in de kunst werden ingezet. Ieder genre had zijn eigen uiterlijke kenmerken, iconografie, doelstellingen en betekenissen waarin vogels een passende plaats kregen, met Schoumans behangsels en aquarellen in zekere zin als grande finale. Gevogelte was een erotisch of religieus symbool, een gewenste buit, een wetenschappelijk interessant fenomeen, een lekkernij of een toonbeeld van schoonheid, afhankelijk van de context. Een definitieve duiding is lang niet altijd mogelijk.

Er zijn tussen i6oo en I80o diverse ontwikkelingen te zien. Werden vogels in de zeventiende eeuw nogal eens als zinnebeeld opgevoerd, in de achttiende eeuw kwam steeds meer de nadruk te liggen op hun biologische kenmerken en decoratieve kracht en het appèl dat zij deden op het gevoel. Een meisje, in I770 of I780 wenend om haar gestorven vogel: dat zou in de zeventiende eeuw heel anders zijn opgevat.

Even uiteenlopend als de presentie en betekenis van vogels in de diverse genres (en soms binnen één genre), was het publiek dat schilderijen met vogels 
kocht: van adellijke jagers en jagende burgers tot wetenschappers en kunstliefhebbers zonder meer. Maar op dit vlak is nog veel kennis te vergaren. Wie de kunsthistorische literatuur doorloopt met het oog op vogels in oude Nederlandse kunst stuit op flinke hiaten. Een paar voorbeelden. Hoeveel kunstenaars hielden zich binnen de diverse genres serieus met vogels bezig? Hoe was hun status en reputatie? Hoe verhielden schilder- en tekenkunst zich op dit vlak? Hoe ontwikkelde zich de relatie tussen kunst en wetenschap ten aanzien van gevogelte? Hoe waren de contacten tussen kunstenaars en kopers? Hoe was het gesteld met eventuele buitenlandse belangstelling voor Nederlandse vogelschilders? Ook de relatie tussen kunst en gebieden als de contemporaine belangstelling voor vogels in het algemeen, jacht en valkerij, vinkenbanen, menagerieën, verzameldrift, de ontwikkelingen in het natuurgevoel verdient nadere research.

Bij toekomstig onderzoek zullen veldbiologie en biohistorie belangrijke impulsen kunnen geven. Vragen naar bijvoorbeeld de herkenning van geschilderde vogels, de precisie waarmee ze zijn weergegeven, het geschilderde soortenspectrum per schilderij en per kunstenaar, de voorkeur voor bepaalde species, het voorkomen en de geografische verspreiding van geschilderde vogels door het jaar heen, hun gesuggereerde biotoop, de toenmalige kennis van vogels, de precieze samenstelling van collecties, de aanwezigheid van exotische vogels in menagerieën en de toegankelijkheid daarvan, de populariteit van vogels in het algemeen bij een breed publiek en daarnaast de geschiedenis van de taxidermie kunnen tot veel nieuwe inzichten leiden in de idealen en de werkwijze van kunstenaars. Vergelijking met de situatie in het buitenland ligt bij dit alles voor de hand.

Omgekeerd kan analyse van historisch visueel materiaal, mits met grote omzichtigheid uitgevoerd, de bioloog gegevens verschaffen over het voorkomen van bepaalde soorten in de zeventiende en achttiende eeuw. De conclusie is gerechtvaardigd dat het goed zal zijn met een frisse blik te kijken naar vogels in schilderijen. Vele van deze kunstwerken zijn zo bekend dat de term 'gevleugelde beelden' gerechtvaardigd is. Maar tegelijkertijd ligt er voor onderzoekers nog veel terrein braak. Het kunst- en natuurminnende publiek is er rijp voor om van hun antwoorden kennis te nemen, via welk medium dan ook.

\section{Noten}

Voor hun kritische lezing van het manuscript dank ik Edward Grasman en Suzanne Laemers. In deze bijdrage schrijf ik, afwijkend van sommige andere auteurs in deze bundel, conform de ornithologische vakliteratuur Nederlandse soortnamen van vogels met een beginkapitaal. Familienamen ('duif', 'pauw') worden met een kleine letter geschreven.

I Om een nog niet volledig opgehelderde reden werden door een onbekend kunstenaar in Enkhuizen van 1598 tot kort na I6ro op een groot paneel 32 eendenkoppen (met een merk op de snavel) en bijbehorende poten geschilderd (Enkhuizen, Zuiderzeemuseum). Zie: R.E.O. Ekkart, met een inleiding van G. Reichwein, Portret van Enkhuizen in de gouden eeuw, Zwolle-Enkhuizen 
I990, p. 44. Bij de notatie van kunstenaarsnamen volg ik de voorkeursnamen van het Rijksbureau voor Kunsthistorische Documentatie (http://website.rkd.nl/Databases/RKDartists). Het aantal verwijzingen is zo beperkt mogelijk gehouden.

2 Voor bloemen, zie o.a.: S. Segal, Flowers and nature. Netherlandish flower painting of four centuries, The Hague I990. Enkele voorbeelden van belangrijke publicaties over 'vogel'onderwerpen zijn: J. Balis, Van diverse pluimage. Tien eeuwen vogelboeken, tent. cat. Antwerpen (Koninklijke Maatschappij voor Dierkunde), 's-Gravenhage (Rijksmuseum Meermanno-Westreenianum) en Brussel (Koninklijke Bibliotheek) I968-I969; E. de Jongh, 'Erotica in vogelperspectief. De dubbelzinnigheid van een reeks zeventiende-eeuwse genrevoorstellingen', in: Idem, Kwesties van betekenis. Thema en motief in de Nederlandse schilderkunst van de zeventiende eeuw, Leiden I995, p. 2I-58; K.J. Müllenmeister, Meer und Land im Licht des 17. Jahrhunderts. Band 2 Q 3 Tierdarstellungen in Werken niederländischer Künstler, Bremen I978 en I98I; S.A. Sullivan, The Dutch gamepiece, Towota and Montclair, New Jersey I984; L.J. Bol, Aart Schouman. Ingenious painer and draughtsman, Doornspijk I99I; Geverfde vogels, special van Kunstschrift 39 (I995), nr. 4; I. Matthey, Vincken moeten vincken locken. Vijfeeuwen vangst van zangvogels en kwartels in Holland, Hilversum 2002; T. Lemaire, Op vleugels van de ziel. Vogels in voorstelling en verbeelding, Amsterdam 2007; M. Rikken, Melchior d'Hondecoeter - Vogelschilder, Amsterdam 2008. De Dictionary of bird artists of the world (Wappingers Falls, NY, I999) van C.E. Jackson is wat de titel belooft en is geen verslag van samenhangend onderzoek.

3 Ik noem er slechts twee: in A. Chong \& W. Kloek, met C. Brusati e.a., Het Nederlandse stilleven 1550-1720. Amsterdam, Cleveland, Zwolle I999 (tent. cat. Amsterdam, Rijksmuseum en Cleveland, The Cleveland Museum of Art I999-2000), cat. nr. 63, p. 249 worden twee Patrijzen Kwartels genoemd. En in J. Streng en L. van Dijk, Zwolle in de Gouden Eeuw. Cultuur en schilderkunst, Zwolle I997 (tent. cat. Stedelijk Museum Zwolle I997), nr. 32, p. 93, wordt in een stilleven van Pieter van Noort een paartje Korhoen geïdentificeerd als Patrijzen.

4 Landschap (buiten het historiestuk) en topografie zijn buiten beschouwing gebleven omdat vogels hierin, als ze al voorkwamen, meestal niet meer dan decoratie zijn.

5 Zie voor de ontwikkeling van het stilleven in het algemeen onder meer: R. van Lutterveld, Schilders van het stilleven, Naarden I947; p. 6I-73 zijn gewijd aan het stilleven met wild en dode vogels. Zie verder: Chong \& Kloek, Het Nederlandse stilleven 1550-1720; A. van der Willigen en F.G. Meijer, A dictionary of Dutch and Flemish still-life painters working in oils, 1525-1725, Leiden 2003; F. Meijer, Catalogue of the collection of paintings [in the Ashmolean Museum, Oxford]: the collection of Dutch and Flemish still-life paintings bequeathed by Daisy Linda Ward, Zwolle 2003. Voor de ontwikkeling van het jachtbuitstilleven: Sullivan, The Dutch gamepiece en: G. Cavalli-Björkman, 'Jaktstilleben', in: Jakten. Konstnärens motiv - jägarens mål, tent. cat. Nationalmuseum (Stockholm) och Stiftelsen Läckö Slott 2003, p. 50-58.

6 Chong \& Kloek, Het Nederlandse stilleven 1550-1720.

7 Voor diens invloed op de vogelstudies van Dürer en Cranach, zie: F. Koreny, Albrecht Dürer und die Tier- und Pflanzenstudien der Renaissance, München I985, p. 47. Via de Web Gallery of Art is een afbeelding van Barbari's Patrijs te vinden: http://www.wga.hu/frames-e.html?/html/b/barbari/ index.html.

8 Chong \& Kloek, Het Nederlandse stilleven 1550-1720, p. 24.

9 Zie: Matthey, Vincken moeten vincken locken. Over de zangvogels die op vinkenbanen werden gevangen: p. I5-33.

Io Zie over Rembrandts schilderij o.a.: J. Loughman, 'De markt voor Nederlandse stillevens, I600-I720’, in: Chong \& Kloek, Het Nederlandse stilleven 1550-1720, p. I94-I97.

II Zie over Jacob en Cornelis Biltius onder meer: B.J.A. Renckens, 'Enkele archivalia en opmerkingen over Jacobus en Cornelis Biltius', Oud-Holland 68 (I953), p. 238-24I; en: Van der Willigen en Meijer, A dictionary of Dutch and Flemish still-life painters, p. 38.

I2 Voor de jacht zie onder meer: Sullivan, The Dutch gamepiece, p. 33-45; en: J.A. Hendrikx, 'Jacht als vermaak voor de elite', in: J. de Jongste, J. Roding en B. Thijs (red.), Vermaak van de elite in de vroegmoderne tijd, Hilversum I999, p. I37-I52. Zie voor de jacht in verband met stillevens o.a.: E. de Jongh, T. van Leeuwen, A. Gasten, H. Sayles, Still-life in the age of Rembrandt, tent. cat. Auckland (Auckland City Art Gallery) I982, p. I35-I36; en: Chong \& Kloek, Het Nederlandse stilleven 1550-1720, 
o.a. p. I9-20. Voor de stedelijke elite die zich vermaakte op vinkenbanen: Matthey, Vincken moeten vincken locken, p. 216-239.

I3 Over de geringe waardering voor het stilleven in de I7de-eeuwse kunsttheorie, zie: G.M.C. Jansen, “"In de laegste rang”; over de positie van het stilleven in de Nederlandse kunstliteratuur van de zeventiende eeuw, in: Chong \& Kloek, Het Nederlandse stilleven 1550-1720, p. 5I-57.

I4 Voor enkele steden is onderzoek verricht naar schilderijenbezit onder de burgerij, maar vaak is de classificatie waarop is gezocht te weinig specifiek om over dit onderwerp meer te weten te komen. Zo deelt Piet Bakker het schilderijenbezit van burgers in Leeuwarden voor de periode I590-I699 in aan de hand van categorieën als 'jacht/batailles', 'levende dieren' en onder stilleven 'wild/vis'. Hieruit is dus niet op te maken hoeveel vogelstukken erbij waren. P. Bakker, Gezicht op Leeuwarden. Schilders in Friesland en de markt voor schilderijen in de Gouden Eeuw, s.1. 2008 (diss. Universiteit van Amsterdam 2008), p. 327.

I5 Loughman, 'De markt voor Nederlandse stillevens', p. 93 en 95. Zie ook p. Io2, tabel 4 met gemiddelde prijzen voor werk van stillevenschilders in de Republiek voor de jaren I620-I7I9.

I6 Zie over de oriëntatie op de Gouden Eeuw na I770 onder meer: L. van Tilborgh en G. Jansen (red.), Op zoek naar de Gouden Eeuw. Nederlandse schilderkunst, 1800-1850, Zwolle I986 (tent. cat. Haarlem, Frans Halsmuseum i986).

I7 R. van Eynden en A. van der Willigen, Geschiedenis der vaderlandsche schilderkunst, sedert de helft der xviı eeuw, Haarlem I8I6-I840 (vier delen), iı , p. I23-I24 (over Jan Hendrik Nicolay). Voor de prijsvragen van Felix Meritis, zie: P. Knolle, 'Het departement der tekenkunde van Felix Meritis', Documentatieblad Werkgroep achttiende eeuw xv/2 [59-60] (I983), p. I4I-I96.

I8 Dat Patrijzen ook nog als wellustig werden beschouwd zal in de meeste stillevens niet meespelen. Zie hierover: De Jongh, 'Erotica in vogelperspectief', p. 28. Voor de betekenis van de Patrijs, zie ook: E. de Jongh e.a., Tot lering en vermaak. Betekenissen van Hollandse genrevoorstellingen uit de zeventiende eeuw, tent. cat. Amsterdam (Rijksmuseum) I976, p. 76-79. Voor de Patrijs in het jachtbuitstilleven, zie o.a.: De Jongh, Van Leeuwen, Gasten, Sayles, Still-life in the age of Rembrandt, p. I39-I43.

I9 J. Stumpel, 'Van veren en verven. Over het mirakel van geschilderd gevogelte in de I7de eeuw, in: Geverfde vogels, p. 36-4I.

20 Zo komt er in Frans Snijders' De Wildkraam (I6I4, The Art Institute of Chicago, Chicago) prominent een dode Kleine Zwaan voor, een vogel die alleen van oktober tot april in de Nederlanden verblijft. Helaas voegen de andere (zang)vogels in het schilderij weinig toe aan deze kennis. Het schilderij is afgebeeld in: Loughman, 'De markt voor Nederlandse stillevens', p. I37.

2I Zoals Alan Chong heeft aangegeven lenen stillevens zich beter dan figuurstukken, waaraan meestal een verhaal ten grondslag ligt, voor meervoudige interpretatie. Zie: A. Chong, 'Wat onder de naam van stilleven begrepen is', in: Chong \& Kloek, Het Nederlandse stilleven 1550-1720, p. 32. Op complicaties bij de interpretatie van stillevens wijst ook E. de Jongh, 'De interpretatie van stillevens: grenzen en mogelijkheden', in: Idem, Kwesties van betekenis. Thema en motief in de Nederlandse schilderkunst van de zeventiende eeuw, Leiden I995, p. I29-I48.

22 Over de symboliek van pauwen, zie: E. de Jongh, 'Hoogmoed en pompeusheid in pauwestaarten en pauwetaarten', in: Geverfde vogels, p. 26-32.

23 Dat een stilleven de rijkdom van de koper kon accentueren, blijkt uit Dode vogels en jachtgerei van Willem van Aelst (I664, Nationalmuseum, Stockholm). Voor het blauw in de IJsvogel en in de fluwelen weitas is ultramarijn gebruikt, een verfstof die werd verkregen uit het dure lapis lazuli. Zie: Loughman, 'De markt voor Nederlandse stillevens', p. 244-246.

24 Zie voor deze opvatting: Chong, 'Wat onder de naam van stilleven begrepen is', p. I9-20.

25 Blijkens een gedicht op een pronkstilleven met papegaai van Jan Davidsz. de Heem uit I655. Loughman, 'De markt voor Nederlandse stillevens', p. I73-I75.

26 Zie o.a. W. Kloek, 'De betovering van het stilleven', in: Chong \& Kloek, Het Nederlandse stilleven 1550-1720, p. 42.

27 K. Thomas, Het verlangen naar de natuur. De veranderende houding tegenover planten en dieren 1500-1800, Amsterdam I990, p. 289-296. 
28 Het Nederlandse I7de-eeuwse historiestuk staat pas sinds de tentoonstelling God en de goden bij een ruimer publiek in de belangstelling. Zie de bijbehorende catalogus: Goden de goden. Verhalen uit de bijbelse en klassieke oudheid door Rembrandt en zijn tijdgenoten, Amsterdam-Den Haag I98I (tent. cat. Washington, National Gallery of Art, Detroit, The Detroit Institute of Arts, Amsterdam, Rijksmuseum I980-I98I).

29 Zie: C. van de Passe, 't Light der teken en schilderkonst. With an introduction by J. Bolten, Soest I978 (oorspronkelijke druk: Amsterdam I643 en verder). Bolten vermeldt in zijn inleiding onder meer het modelboek van Pieter de Jode uit I629 en Abraham Bloemaerts Konstrijk tekenboek waarin delen aan vogels zijn gewijd.

30 'Orpheus betovert de dieren', ontleend aan Ovidius' Metamorfosen, werd door onder meer Pieter Boel, Aelbert Cuyp en vooral Roelant Savery geschilderd. Orpheus bespeelde, nadat hij afscheid had moeten nemen van zijn overleden geliefde Eurydice, in de natuur zijn harp (soms een viool) zo lieflijk dat overal vandaan dieren naar hem toe kwamen, ook vele vogels, die hij alle betoverde. Soms is Orpheus minuscuul afgebeeld en nemen de dieren visueel de hoofdrol voor hun rekening. Onder de vogels zien we steeds Europese en exotische soorten - van Kraanvogels tot kaketoes en Struisvogels - verenigd in een fantasielandschap. Cuyp koos zelfs voor een rivierlandschap dat doet denken aan zijn Dordtse omgeving.

3I P. Schoon en S. Paarlberg (eindred.), Griekse goden en helden in de tijd van Rubens en Rembrandt, Athene-Dordrecht 2000 (tent. cat. Nationale Pinakotheek/Nederlands Instituut, Athene 2000-200I en Dordrechts Museum, Dordrecht 200I), cat. nr. 70, p. 296.

32 Zie F. Koreny, Albrecht Dürer und die Tier- und Pflanzenstudien; en: M.-C. Maselius, A. Balis en R.H. Marijnissen, De albums van Anselmus de Boodt (1550-1632). Geschilderde natuurobservatie aan het hof van Rudolf II te Praag, Tielt I989.

33 Voor de uiteenlopende interpretaties van dit verhaal, waaronder Ganymedes als Waterman, zie: Schoon en Paarlberg, Griekse goden en helden. En over Ganymedes ook: E. de Jongh e.a., Tot lering en vermaak, p. I30-I33.

34 Hoe bijna onwerkbaar veel zinnebeeldige betekenissen vogels zoals pauw, Knobbelzwaan of Patrijs konden hebben, wordt duidelijk uit: S. en L. Dittrich, Lexikon der Tiersymbole. Tiere als Sinnbilder in der Malerei des 14.-17. Jahrhunderts, Petersberg $2005^{2}$ (Studien zur internationalen Architektur- und Kunstgeschichte 22).

35 E. de Jongh, Zinne- en minnebeelden in de schilderkunst van de zeventiende eeuw, Amsterdam I967, p. 68; en: J.P. Filedt Kok, R. Baarsen, B. Cornelis e.a., Nederlandse kunst in het Rijksmuseum 1600-1700, Zwolle-Amsterdam 200I, p. I47-I48.

36 Zie voor vogels in de genreschilderkunst onder meer: De Jongh, Zinne- en minnebeelden; De Jongh e.a., Tot lering en vermaak; en: De Jongh, 'Erotica in vogelperspectief'.

37 Een goed voorbeeld is een schilderij van Pieter Codde uit I635 (Rijksmuseum, Amsterdam, particulier bruikleen) waarin twee jagers na de jacht demonstratief een haas en twee Patrijzen binnenbrengen in een kamer met vier dames. Zie: De Jongh e.a., Tot lering en vermaak, p. 76-79.

38 Zo werd het spreekwoord 'Wat baeter kaers of bril, als den uijl niet sien en wil' regelmatig in de schilder- en prentkunst verbeeld. Hiervoor stonden overigens uiteenlopende uilensoorten model, waaronder de Kerkuil. Daarnaast werd de uil verbonden met dronkenschap, zoals blijkt uit zegswijzen als 'hij is zo beschonken als een uil' of 'zo zat als een uil'. Zie: De Jongh e.a., Tot lering en vermaak, p. 246-249.

39 De Jongh, 'Erotica in vogelperspectief', p. 43.

40 De Jongh, Zinne- en minnebeelden, p. 42 e.v.

4I Zie over dit portret: E. Runia, 'Schilderij op reis. Michiel Pompe in Den Haag', Bulletin Dordrechts Museum 32 (2007), nr. 4, p. I4-I5.

42 Bij het samenstellen van deze samenvatting van leven en werk van Hondecoeter is dankbaar gebruik gemaakt van: Rikken, Hondecoeter.

43 Rikken, Hondecoeter, p. 20.

44 Idem, p. 26 en 33-37. Zie voor een voorbeeld van Snijders' gebruik van fabels: De Jongh, Zinne-en minnebeelden, p. I8. 
45 De frequentie waarmee in Nederland pluimveestukken werden geschilderd zegt, behalve over de aantrekkelijkheid van dit genre, waarschijnlijk ook iets over de populariteit van kippen. Voor het houden van pluimvee in Nederland, zie: B. Mombarg, Houden van kippen. Een historisch sociologische analyse van de georganiseerde raspluimveeteelt, diss. Groningen 2000.

46 Zie hier ook de bijdrage van Kester Freriks, waarin hij onder andere de plafondschilderingen van valkenjachttaferelen in het KNAw/Trippenhuis in Amsterdam bespreekt.

47 Voor een inventarisatie van Nederlandse menagerieën en naturaliënkabinetten, zie: P. Smit, Hendrik Engel's alphabetical list of Dutch zoological cabinets and menageries. Second, enlarged edition prepared by Pieter Smit with the assistence of A.P.M. Sanders and J.P.F. van der Veer, Amsterdam I986 (Nieuwe Nederlandse bijdragen tot de geschiedenis der geneeskunde en der natuurwetenschappen no. 19).

48 A. Houbraken, De groote schouburgh der Nederlantsche konstschilders en schilderessen. (...), 's-Gravenhage I7532 ${ }^{2}$, III, p. 274-275. Adriaen van Eemont schilderde voorzover bekend vooral landschappen.

49 Soms kan een landhuis op de achtergrond worden geïdentificeerd waardoor de opdrachtgever kan worden achterhaald. Zie: Rikken, Hondecoeter, p. 3I.

50 Zie voor de opdrachten van Willem in: Rikken, Hondecoeter, p. 38 e.v.

5 I Idem, p. 42.

52 F. Grijzenhout, “Na 't leven geteekent in de diergaarde van Zijne Hoogheit”. Kunstenaars rond de menagerie van Prins Willem v', in: B.C. Sliggers en A.A. Wertheim (red.), Een vorstelijke dierentuin. De menagerie van Willem v, Haarlem-Parijs-Zutphen I994, p. 75.

53 Sinds de I6de eeuw had menig heerser een menagerie. Zie onder meer: Grijzenhout, 'Na 't leven geteekent', p. 6I-86; en: J. Reynaerts, The king, the painter and the lion, Amsterdam 2006, p. 3I.

54 Bijvoorbeeld in de bekende menagerie van Blauw Jan in Amsterdam. Ook in de I8de eeuw was dit niet ongebruikelijk. In de menagerie op de buitenplaats 't Middelhoff bij Oostkapelle van de jurist Kornelis van der Helm Boddaert liepen, blijkens een tekening uit I772, 'wilde' vogels en sierkippen door elkaar. Zie: B.C. Sliggers, M.H. Besselink (red.), Het verdwenen museum. Natuurhistorische verzamelingen 1750-1850, Blaricum-Haarlem 2002, p. I64 en I68.

55 Het verhaal van de gedresseerde haan staat in: Houbraken, De groote schouburgh, III, p. 72.

56 Voor Coorte en Weenix en voor Hondecoeters populariteit na zijn dood, zie: Rikken, Hondecoeter, p. $53-54$ en 58. Voor Van Oolen, zie: Houbraken, De groote schouburgh, III, 320.

57 Over Schouman, zie onder meer: Herdenkingstentoonstelling Aart Schouman 1710-1792, Dordrecht, Dordrechts Museum I960; L.J. Bol, Aart Schouman. Ingenious painer and draughtsman, Doornspijk I99I; Rikken, Hondecoeter, p. 6o-6I.

58 Sliggers, Pieters, Besselink e.a., Het verdwenen museum, afb. p. I2.

59 Over Regnum animale, zie: F. Pieters en K. Rookmaaker, 'Arnout Vosmaer, topcollectioneur van naturalia en zijn Regnum animale', in: Sliggers en Wertheim, Een vorstelijke dierentuin, p. II-38. Over menagerie en kabinet van Willem v: F. Pieters, 'De menagerie van stadhouder Willem v op Het Kleine Loo te Voorburg', in: Sliggers en Wertheim, Een vorstelijke dierentuin, p. 39-59; en: F. Pieters, 'Het schatrijke naturaliënkabinet van Stadhouder Willem v onder directoraat van topverzamelaar Arnout Vosmaer', in: Sliggers, Pieters, Besselink e.a., Het verdwenen museum, p. I9-44.

60 Zie over dit boek: Balis, Van diverse pluimage, p. 50-52; en: C. Nissen, Die illustrierten Vogelbücher. Ihre geschichte und Bibliographie, Stuttgart I953, p. 45 en I50. Theoloog, predikant en natuurliefhebber Nozeman, verantwoordelijk voor het eerste deel, beschrijft in deze rijk geillustreerde eerste Nederlandse avifauna het verenkleed van mannetjes en vrouwtjes zo nauwkeurig mogelijk en bespreekt, wat voor zijn tijd uitzonderlijk was, de eieren, de nesten en de habitat.

6I Zie voor prenten in vogelboeken onder meer: Balis, Van diverse pluimage.

Zie in deze bundel ook de bijdrage van Hansjorg Ahrens over de wetenschappelijke illustratietraditie van Naturalis.

62 Zoals die van de medicus-botanicus Martinus Wilhelmus Schwencke, ene heer Hulle, Abraham Laporte, mevrouw C.M. Sirtema van Grovestins geb. Sinolt genaamd von Schutz (hofdame van prinses Anna en echtgenote van de stadhouderlijke opperstalmeester Douwe Sirtema van 
Grovestins), Tak in Rotterdam, J.E. Voet in Dordrecht, de verzamelaars van onder meer schilderijen en schelpen Jan en Pieter Bisschop in Rotterdam, Abraham de Clerck in Middelburg (die volgens Arnout Vosmaer een collectie prachtig opgezette vogels had), Arnout Geverts in Rotterdam en Van Heeteren. Bol, Schouman, p. 88. Voor het kabinet van mevrouw Grovestins, zie ook: Th.H. Lunsingh Scheurleer, 'Twee achttiende-eeuwse naturaliënkabinetten', Nederlands Kunsthistorisch Jaarboek 2I (I970), p. 225 e.v.

63 Voor het bijeenbrengen van naturalia, zie: E. Bergvelt en R. Kistemaker (red.), De wereld binnen handbereik. Nederlandse kunst- en rariteitenverzamelingen, 1585-1735, Zwolle I992; E. Bergvelt en R. Kistemaker, (red.), De wereld binnen handbereik. Nederlandse kunst-en rariteitenverzamelingen, 1585-1735, Amsterdam-Zwolle i992 (tent. cat. Amsterdam, Amsterdams Historisch Museum). Zie verder diverse bijdragen in: E. Bergvelt, D.J. Meijers, M. Rijnders (red.), Kabinetten, galerijen en musea. Het verzamelen en presenteren van naturalia en kunst van 1500 tot heden, Heerlen-Zwolle 2005; E. Bergvelt, M. Jonker, A. Wiechmann (red.), Schatten in Delft. Burgers verzamelen 1600-1750. 16022002, 400 jaar Verenigde Oost-Indische Compagnie, Zwolle-Delft 2002; en: Sliggers \& Besselink e.a., Het verdwenen museum.

64 Ellinoor Bergvelt noemt in haar 'Verantwoording' in Bergvelt, Jonker, Wiechmann, Schatten in Delft, p. 24, vijf motieven om te verzamelen: het streven naar of behouden van status, investering, religieuze overtuiging, zintuiglijk plezier (of esthetiek) en wetenschappelijke nieuwsgierigheid. Ongetwijfeld zal modebewustzijn (het opbouwen van een verzameling naturalia 'hoorde' bij een bepaalde status) ook een rol hebben gespeeld. Zie voor religieuze motieven van verzamelaars ook: E. Jorink, Het Boeck der Natuere. Nederlandse geleerden en de wonderen van Gods Schepping 1575-1715, Leiden 2007.

65 Grijzenhout, 'Na 't leven geteekent', p. 82 en 84 .

66 Van de volgens de veilingcatalogus van I792 meer dan 200 bloemaquarellen van Schouman was in I991 niet meer dan ruim I0\% nog bekend. Zie Bol, Schouman, p. 77. Zie verder: M. van Berge-Gerbaud, M. Menalda, M.C. Plomp, C. van Tuyll van Serooskerken, Hartstochtelijk verzameld. Beroemde tekeningen in 18de-eeuwse Hollandse collecties, Parijs-Bussum 200I (verschenen bij de gelijknamige tentoonstelling, Haarlem (Teylers Museum) en Parijs (Institut Néerlandais)), p. I97-I98.

67 Bol, Schouman, p. 94.

68 M.C. Plomp, "Een voortreffelyke Liefhebberye". Het verzamelen van tekeningen door voorname liefhebbers in de Republiek en later het Koninkrijk der Nederlanden, 1732-1833, Groningen 2002 (twee delen; diss. Rijksuniversiteit Groningen), p. 90. Voor Nederlandse verzamelaars van natuurtekeningen, zie ook: M.C. Plomp, Hartstochtelijk verzameld. 18de-eeuwse Hollandse verzamelaars van tekeningen en hun collecties, Parijs-Bussum 200I, p. 227-229 en 250-253.

69 Van Eynden en Van der Willigen, Geschiedenis der vaderlandsche schilderkunst, II, p. 68-73 over Schouman.

70 Bol, Schouman, p. 83 .

7 I Idem, p. 84.

72 Afgebeeld in Bol, Schouman, afb. 93.

73 Grijzenhout, 'Na 't leven geteekent', p. 39 en 79-80.

74 Zie voor de foto's: Herdenkingstentoonstelling Aart Schouman 1710-1792, afb. 6o-63.

75 Zie hierover ook mijn bijdrage aan de catalogus bij de afscheidstentoonstelling voor de directeur van het Dordrechts Museum, Jup de Groot, Kopen voor de eeuwigheid. Verzamelen in het Dordrechts Museum 1975-2000, cat. tent. Dordrechts Museum 2000, p. I86-I87 en de daar vermelde literatuur.

76 Van Berge-Gerbaud, Menalda, Plomp, Van Tuyll van Serooskerken, Hartstochtelijk verzameld, p. I93-194.

77 Houbraken, De groote schouburgh, I, p. I77-I78.

78 Van Eynden en Van der Willigen, Geschiedenis der vaderlandsche schilderkunst, II , p. I23-I24 en IV, p. 27, vermelden de tentoonstellingen van I8I4, I8I6, I8I8, I820 en I822. Ook de Delftse schilder en tekenleraar Izaak van Haastert was een 'liefhebber van de natuurlijke Historie'. Idem, Geschiedenis, Iv, p. 48-49. 
PL. YIII.

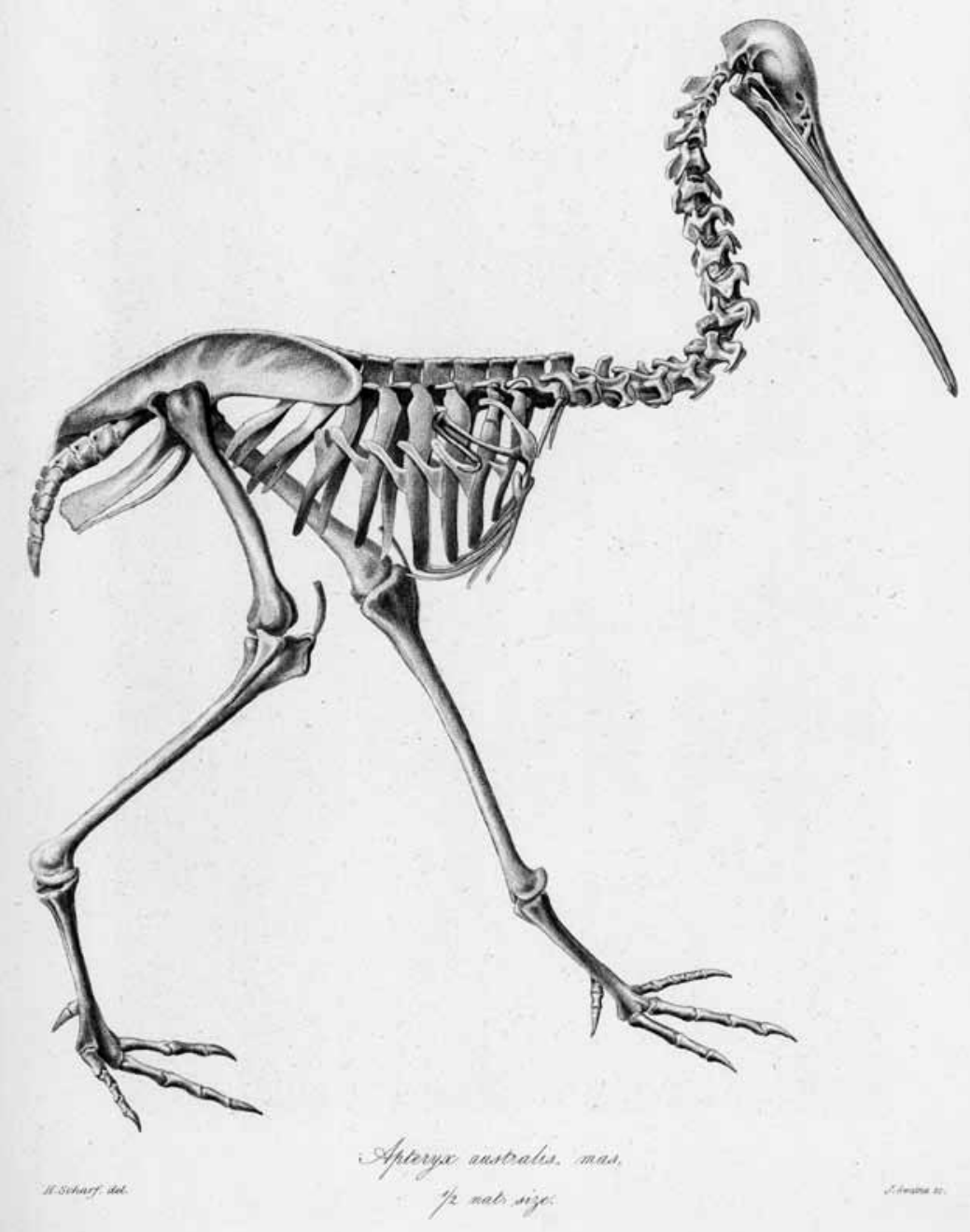

Apteryx australis, skeleton, uit: Richard Owen, Memoirs on the Extinct Wingless birds of New Zealand, London 1879. Bron: KNAw-bibliotheek, IISG Amsterdam 